\title{
Managing ditches for agroecological engineering of landscape. A review
}

\author{
Jeanne Dollinger ${ }^{1}$ - Cécile Dagès ${ }^{1}$ Jean-Stéphane Bailly ${ }^{2}$ Philippe Lagacherie ${ }^{1}$. \\ Marc Voltz ${ }^{1}$
}

Accepted: 17 March 2015 / Published online: 24 April 2015

(C) INRA and Springer-Verlag France 2015

\begin{abstract}
Agriculture must now feed the planet with the lowest environmental impact. Landscape management is a means to protect natural resources from the adverse impacts. In particular, the adequate management of ditches could improve crop quality. Here, we review ditch design and maintenance. We found the following major points: (1) ditch networks have been primarily designed for waterlogging control and erosion prevention. Nonetheless, when properly managed, farm ditches provide other important ecosystem services, namely groundwater recharge, flood attenuation, water purification, or biodiversity conservation. (2) All ditch ecosystem services depend on many geochemical, geophysical, and biological processes, whose occurrence and intensity vary largely with ditch characteristics. (3) The major ruling characteristics are vegetative cover; ditch morphology; slope orientation; reach connections such as piped sections and weirs, soil, sediment and litter properties, biota, and biofilms; and network topology. (4) Ditch maintenance is an efficient engineering tool to optimize ecosystem services because several ditch characteristics change widely with ditch maintenance. For instance, maintenance operations, dredging, chemical weeding, and burning improve waterlogging and soil erosion control, but
\end{abstract}

Cécile Dagès

dages@supagro.inra.fr

1 INRA, UMR LISAH, 2, Place Pierre Viala, 34060 Montpellier Cedex 1, France

2 AgroParisTech, UMR LISAH, 2, Place Pierre Viala, 34060 Montpellier Cedex 1, France they are negative for biodiversity conservation. Mowing has low adverse effects on biodiversity conservation and water purification when mowing is performed at an adequate season. The effects of burning have been poorly investigated.

Keywords Ditch · Ecosystem services · Farmed landscape · Management $\cdot$ Maintenance operation $\cdot$ Landscape processes . Water purification · Waterlogging control · Erosion control . Biodiversity conservation

\section{Contents}

1. Introduction

2. Methodology

3. Ecosystem services performed by ditches: mechanisms and optimization conditions

3.1 Waterlogging control

3.2 Soil erosion prevention

3.3 Groundwater recharge

3.4 Flood regulation

3.5 Water purification

3.5.1 Ditch networks: pollutants collectors and propagation pathways

3.5.2 Sediment retention in ditches

3.5.3 Nutrient retention in ditches

3.5.4 Pesticide retention in ditches

3.6 Biodiversity conservation

3.7 Intricacy and control factors of the ecosystem services provided by ditches

4. Ditch maintenance: lever for the optimization of ecosystem services 
4.1 Impact of maintenance operations on ditch characteristics

4.2 Maintenance effect on the processes and services

4.3 Designing maintenance toward an optimization of ecosystem services

5. Conclusion

\section{Introduction}

Agriculture faces the challenge of "feeding the planet" while minimizing its impact on the environment. Indeed, intensive agriculture is involved in soil and water pollution, soil losses by erosion, and biodiversity erosion. Strategies to limit the adverse environmental effects of agriculture emerged in the late 1980s and early 1990s in North America and in Europe, with the Best Management Practices and the AgriEnvironmental Schemes, respectively. In addition to recommendations for farmed field practices, these strategies include recommendations on field margin management, such as the preservation and maintenance of terraces, hillslope and drainage ditches, and grassed strips (Logan 1993).

Among these field margins, farm ditches play a significant role in many issues of agricultural landscapes. Farm ditches are human-made linear elements that constitute the upstream parts of the permanent hydrographic networks in agricultural landscapes. Primarily implanted within farmed landscape to collect surface and subsurface water in order to drain excess water and/or to prevent soil erosion, farm ditches may also control pollution and preserve biodiversity (Herzon and Helenius 2008). In the USA, vegetated ditches are the objects of Best Management Practices for their nutrient and pesticide retention capacities (Cooper et al. 2004; Dabney et al. 2006; Kröger et al. 2013; Moore et al. 2001). In The Netherlands, the management of ditch sidewalls to enhance plant species diversity is one of the most widely implemented AgriEnvironmental Schemes (van Dijk et al. 2014; Leng et al. 2011). Other studies or reviews indicate that ditch management should be included in the agri-environmental measures of other European countries, such as farmland bird protection in the UK (Bradbury and Kirby 2006) or wetland ecosystem maintenance in the UK (Gavin 2003) or in Germany (Langheinrich et al. 2004). Considering the abovementioned functions, ditches can be seen as providers of regulating ecosystem services according to the classification of Millennium Ecosystem Assessment (2005). The services that are provided by ditches include soil waterlogging and erosion control, which are the initial drivers for ditch creation given their impact on crop production. But, they also extend to water purification, flood regulation, groundwater recharge, and biodiversity conservation.
The maximization of the ecosystem services that are provided by ditches requires an adequate design of the ditch characteristics and maintenance. The ditch characteristics of interest are either structural as shape parameters (length, slope, and cross section); connectivity between fields and ditches; ditch network topologies; bed and sidewall properties (soil texture and structure); or functional characteristics such as litter, vegetation nature, and covering (Herzon and Helenius 2008; Lagacherie et al. 2006). Ditch maintenance is a combination in time of dredging, mowing, chemical weeding, and burning (Fig. 1) techniques (Needelman et al. 2007; Kröger et al. 2009; Levavasseur et al. 2014). Designing the best ditch characteristics and maintenance practices requires a thorough knowledge of their impacts on the underlying biotic and abiotic processes that are involved in the provision of the expected ecosystem services.

So far, only lowland drainage ditches have been the focus of reviews concerning either their hydrological functioning and engineering (Skaggs and Schilfgaarde 1999; Skaggs et al. 2005) or their biological importance in the maintenance or restoration of biodiversity (Herzon and Helenius 2008). In addition, Needelman et al. (2007) gathered, in an overview, some case studies mainly focusing on nitrogen and phosphorus with regard to drainage ditch maintenance practices that are suitable for water quality protection. These last two papers (Herzon and Helenius 2008; Needelman et al. 2007) described the role of ditches with respect to water, nutrients, sediment transfer or retention, pollination, pest control, and habitat provision. Both of these papers mentioned the impact of ditches on pesticide fate but, due to a lack of studies, did not highlight the complexity of this impact due to numerous molecules exhibiting a large range of chemical properties and, in turn, behaviors. From 2008, however, several case studies explored the retention ability of vegetated ditches depending on the pesticide chemical properties (Elsaesser et al. 2013; Gill et al. 2008; Moore et al. 2011; Passeport et al. 2011a), now enabling a more comprehensive review on pesticide fate in ditches. In their reviews, Herzon and Helenius (2008) and Needelman et al. (2007) indicated that drainage ditches can be managed for multiple functions, providing examples of management practices with positive effects. Nevertheless, these authors did not provide a comprehensive analysis of the impacts of ditch management, whether positive or negative, on the range of regulating services that are potentially provided by ditches. This analysis requires an in-depth review on how ditch management modifies the ditch characteristics and may, in turn, impact the processes and the provision of services. In addition, it must be underlined that the reviews of Herzon and Helenius (2008) and Needelman et al. (2007) did not consider the ditches that are located in highlands, arid, and semi-arid areas, which act as intermittent streams and can play a significant role in groundwater recharge (Batlle-Aguilar and Cook 2012; Dages et al. 2009) and groundwater contamination (Burkart et al. 1999; Field et al. 2003). 
Fig. 1 Ditch maintenance. Ditch maintenance is a combination and a succession in time of four basic operations namely dredging, mowing, chemical weeding, and burning. On top: dredging on the left and chemical weeding on the right. On the bottom: burning on the left and mowing on the right. Note that ditch maintenance operations exert a strong influence on several important ditch characteristics and, in turn, the provision of ecosystem services
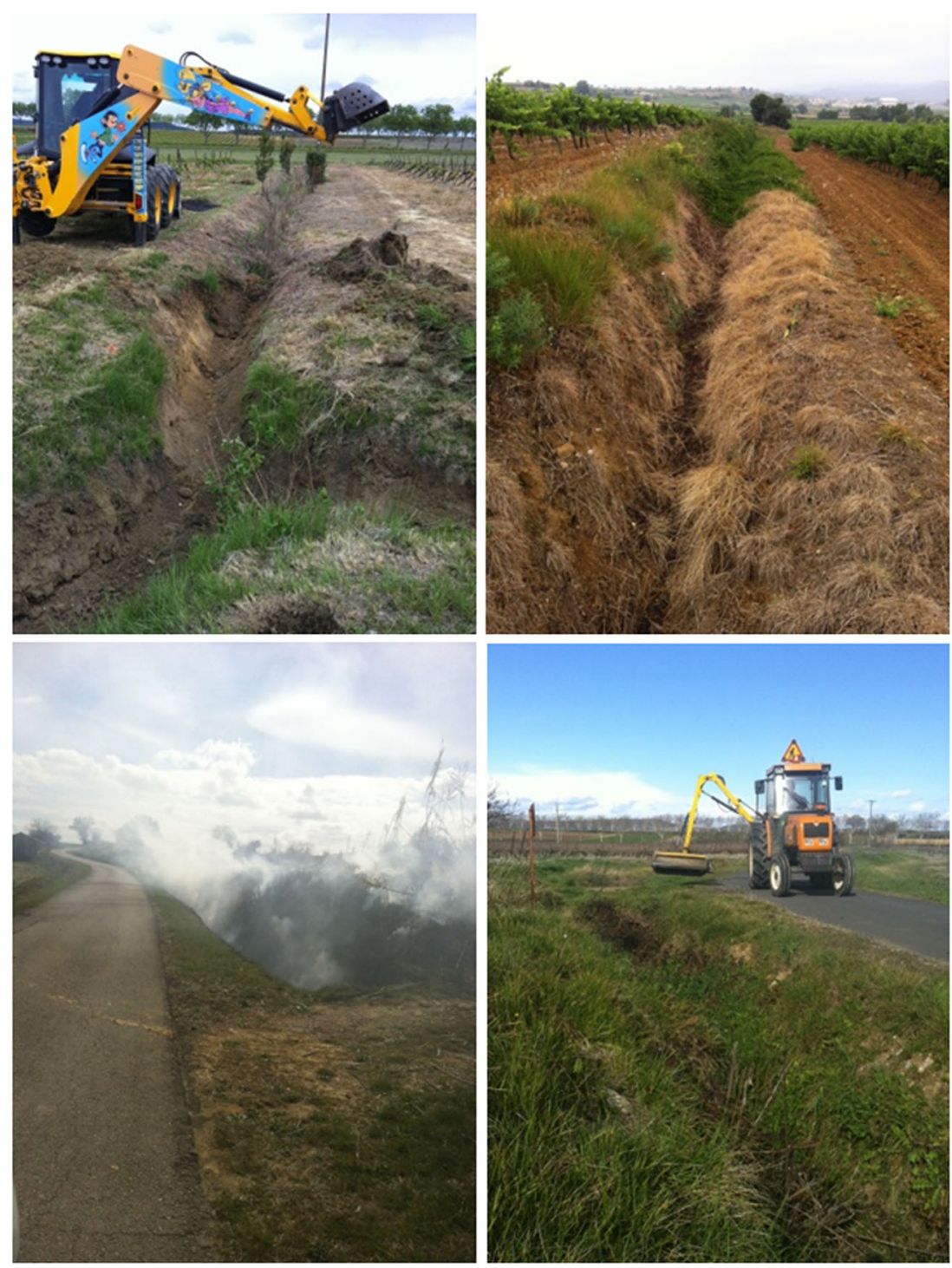

The main aim of this review is to determine whether and how the design of ditches and their maintenance can be useful for the agroecological engineering of landscapes. In this respect, three successive questions are addressed:

1. What is known about the ecosystem services provided by ditches and how do they depend on the processes occurring in ditches and on the ditch characteristics?

2. How can ditch maintenance improve the positive influence of ditches on ecosystem services and avoid adverse effects?

3. What are the future research needs in relation to the previous questions?

The ditches that were considered in this review are humanmade channels forming the upstream part of hydrological networks located both in lowland and in highland areas. In comparison to the previous reviews mentioned above, three particular and supplemental focuses are given here. First, the role of ditches in highland and arid or semi-arid areas is highlighted, as they were poorly considered by previous reviews (Herzon and Helenius 2008; Needelman et al. 2007). Second, the role of ditches on the abiotic processes is especially emphasized since the biological functioning of ditches has been extensively reviewed by Herzon and Helenius (2008). The last focus concerns the maintenance operations and the way that they impact the ditch characteristics and, in turn, processes and ecosystem services provided by ditches.

In the following, we first review the ecosystem services and disservices that are provided by ditches and the processes involved. We then review the contexts and characteristics modulating the intensity of the processes. Finally, we examine the impacts of ditch maintenance on ditch characteristics and, consequently, on the related processes and services. 


\section{Methodology}

To collect and process the available scientific material dealing with the whole chain "ditch maintenance-ditch characteristicsprocesses-ecosystem services" for a diversity of pedoclimatic contexts, we conducted three extensive literature searches in five different scientific databases (ISI Web of Knowledge, Science Direct, Wiley Online Library, Springer Link, and Google Scholar).

- A first search aimed at collecting the papers that studied the involvement of ditches in the provision of ecosystem services. Accordingly, we associated the keywords "ditch", "open-channel", "intermittent stream" individually with each of the following keywords: "ecosystem services", "hydrology", "pollutants", "sediments", "erosion", "nutrient", "pesticides", and "biodiversity".

- A second search aimed at collecting papers describing the processes involved in the provision of ecosystem services and how they are affected by ditch characteristics. We therefore associated the keyword ditch with the search terms corresponding to the processes ("runoff", "drainage", "infiltration", "sedimentation", "plant uptake", "sorption", "degradation", etc.).

- A third search aimed at collecting papers studying the nature and impact of management practices in ditches. Therefore, we associated the keywords ditch, "maintenance", and "management".

Among the pool of collected papers, about $25 \%$ were well focused on the topic of this review. The 140 papers selected gather case studies at different scales, microcosms, mesocosms, ditch and ditch networks, and numerical experiments. The analysis of the papers was then conducted in the aim of documenting the key questions evoked above.

Hereafter, structural characteristics or functional characteristics will be designed by the general term "ditch characteristics."

\section{Ecosystem services performed by ditches: mechanisms and optimization conditions}

Ditches perform several ecosystem services resulting from a combination of geochemical, geophysical, and biological processes (Fig. 2). These services vary among ditches according to the pedoclimatic contexts, ditch characteristics, and anthropogenic drivers. Moreover, ecosystem services provided by ditches may be valued as positive or negative (dis-services), may concern either the reach or the network or both, and may have changing values across pedoclimatic contexts. In the following, ecosystem services provided by ditches are first independently reviewed considering successively the hydrological, pollutant fate, and biological functioning of ditches.
Each subsection aims at describing one ecosystem service provided by ditches, identifying the processes involved either in a positive or negative way, and the pedoclimatic and intrinsic characteristics influencing the occurrence and intensity of these processes. Then, in the final part of the section, the intricacy and main control factors of the range of ecosystem services are exposed. Figure 2 illustrates the main processes, and the way that they are involved in the provision of ecosystem services is summarized in Table 1.

\subsection{Waterlogging control}

In many areas worldwide, agriculture has developed on wetlands in which cropping was enabled by removing excess water via surface drainage or tile drain networks. In France, approximately $10 \%$ of the cropped areas are artificially drained ("Agreste" 2010), whereas this proportion can exceed $50 \%$ in some states in the USA (Skaggs 1992) or in Scotland (Abbot and Leeds-Harrison 1998; Blann et al. 2009). The benefits of agricultural drainage are (i) increasing the crop yields by limiting the anoxic conditions and decreasing plant disease or insect infestation risks and (ii) extending the time for machinery operations (Rosenzweig et al. 2002). Rosenzweig et al. (2002) reported that, in the Midwestern USA, agricultural production damages that are related to excess soil moisture, i.e., a lack of agricultural drainage, can be up to five times higher than the direct damages due to crop submersion by floods. Moreover, ditches, as the collectors of tile drainage systems, also play a role in other subsurface drainage functions, e.g., soil salinity control (Christen et al. 2001; Ritzema et al. 2008) especially in irrigated areas. Finally, D'Itri and Belcher (1994) also mentioned that field drainage associated with water level regulation in ditches controls the minimum water table level during the dry season for crop subirrigation. In northern America, subirrigation, i.e., subsurface irrigation, has enabled increases of yields from 12 to $48 \%$ for maize and soybean (D'Itri and Belcher 1994).

The benefits of waterlogging control vary with the pedoclimatic context. The positive impact of waterlogging control on crop production is rather limited in dry areas with relatively deep groundwater. However, it is of great significance in lowland areas with perennial shallow groundwater or in irrigated areas, where excess water needs to be removed. Waterlogging control results from groundwater table lowering by groundwater exfiltration to the ditches, efficient surface runoff collection, and rapid water routing downstream $\mathrm{Bu}-$ chanan et al. 2012; Girard et al. 2011; Kao et al. 2002; Needelman et al. 2007). This ecosystem service is thereby optimized if all of the three processes involved are maximized (Table 1). The occurrence and intensity of these processes may change across pedoclimatic contexts and ditches or ditch network characteristics as described hereafter. 
Table 1 Classification of the major effects of the main processes taking place in ditches on ecosystem services

\begin{tabular}{|c|c|c|c|c|c|c|c|c|c|}
\hline \multirow[t]{3}{*}{ Processes } & & \multicolumn{8}{|c|}{ Landscape services } \\
\hline & & \multirow{2}{*}{$\begin{array}{l}\text { Waterlogging } \\
\text { control }\end{array}$} & \multirow{2}{*}{$\begin{array}{l}\text { Soil erosion } \\
\text { prevention }\end{array}$} & \multirow{2}{*}{$\begin{array}{l}\text { Flood } \\
\text { regulation }\end{array}$} & \multirow{2}{*}{$\begin{array}{l}\text { Groundwater } \\
\text { recharge }\end{array}$} & \multicolumn{3}{|c|}{ Water purification } & \multirow{2}{*}{$\begin{array}{l}\text { Biodiversity } \\
\text { conservation }\end{array}$} \\
\hline & & & & & & Sediments & Pesticides & Nutrients & \\
\hline \multirow[t]{4}{*}{ Hydrology } & Runoff collection & + & + & - & + & $-/(+)$ & $-/(+)$ & $-/(+)$ & $+/-$ \\
\hline & $\begin{array}{l}\text { Subsurface water } \\
\text { collection }\end{array}$ & + & + & - & & $-/(+)$ & $-/(+)$ & $-/(+)$ & $+/-$ \\
\hline & Infiltration & & & + & + & + & $+/-$ & $+/-$ & $+/-$ \\
\hline & Water conveyance & + & + & - & - & - & - & - & $+/-$ \\
\hline \multirow[t]{2}{*}{ Erosion } & Sedimentation & & & & & + & + & + & $+/-$ \\
\hline & $\begin{array}{l}\text { Transport and } \\
\text { remobilization }\end{array}$ & & & & & - & - & - & - \\
\hline \multirow[t]{3}{*}{ Pesticides } & Sorption & & & & & & + & & + \\
\hline & Degradation & & & & & & + & & $(+/-)$ \\
\hline & Plant uptake & & & & & & + & & - \\
\hline \multirow[t]{3}{*}{ Nutrients } & Sorption & & & & & & & + & $+/-$ \\
\hline & Transformation & & & & & & & + & $+/-$ \\
\hline & Plant uptake & & & & & & & + & $+/-$ \\
\hline \multirow[t]{4}{*}{ Biodiversity } & plant uptake & & & & & & & & \\
\hline & Providing habitat & & & & & & $(+)$ & $(+)$ & + \\
\hline & Sheltering & & & & & & & & + \\
\hline & $\begin{array}{l}\text { Population } \\
\text { connection }\end{array}$ & & & & & & & & + \\
\hline
\end{tabular}

Ecosystem services result from a combination of processes with either positive or negative effects. Direct effects are considered and indirect effects are indicated in brackets. When boxes are unfilled, there is no known relation between the given processes and services. Note that a given process may have both positive and negative effects across the range of ecosystem services considered for ditches. The maximization of a given process may thereby contribute to the optimization of one service and the attenuation of another

+ positive effect of the given processes on ecosystem services, - negative effect of the given processes on ecosystem services

Ditches collect surface runoff from surrounding plots and roads (Buchanan et al. 2012; Carluer and Marsily 2004; Girard et al. 2011). The amount of runoff collected by ditches depends on the runoff that is produced in connected areas and on the ability of the ditches to capture it. In semi-arid areas, surface runoff fluxes may constitute the major proportion of the total water flow in ditch networks whereas this proportion is reduced under continental humid climates (Dages et al. 2009; Buchanan et al. 2012).

The ability of ditches to capture runoff fluxes is related to several ditch characteristics. The ditch morphology determines its storage capacity and the surface area of the connected zones where runoff is generated (Levavasseur et al. 2012; Tucker and Bras 1998). The locations of the ditches within the watershed and their orientation with regard to the slope impact their interception efficiency, which is greater if the ditches are perpendicular to the slope (Carluer and Marsily 2004). The designs of ditch networks, including reach morphology, reach branching, and density, are also strongly related to the runoff capture efficiency (Levavasseur et al. 2012; Zhang et al. 2013). Moreover, it is expected that the influence of plotstream connections on runoff interception (Bracken et al.
2013) is similar to that of plot-ditch connections, although this has not been demonstrated.

Ditches intercept and drain shallow water tables (Hillel 1998; Skaggs 1992) and collect subsurface water from tilldrainage systems (Loumagne and Tallec 2013). The exfiltration of shallow groundwater depends on the climate and may undergo seasonal variations (Blann et al. 2009; Debieche et al. 2006; Koivusalo et al. 2008; Loumagne and Tallec 2013).

Subsurface water collection by ditches is related to several main factors. One factor is the relative depth between the ditch bed and the groundwater level, which controls the extent of the seepage area and the hydraulic gradient. Subsurface water collection is also closely linked to the ditch network design and especially to the reach morphology and density (Dunn and Mackay 1996; Childs and Youngs 2006). The other factors are the hydraulic characteristics of the ditch-groundwater interface, especially the hydraulic conductivity (Carluer and Marsily 2004; Girard et al. 2011). The hydraulic conductivity of ditch sidewalls and beds is related to soil texture and structure and to the sediment and litter layers. They can differ largely from those of the neighboring soil (Marofi 1999; 
Fig. 2 Geochemical, geophysical, and biological processes occurring within ditches that modify the hydrological, pollutant fate, and biodiversity functioning of cultivated landscapes. These processes are drainage water collection (1), runoff collection (2), water conveyance (3), exfiltration (3), infiltration (3), population connection (4), shelter provision (5), habitat provision (5), sedimentation (6), plant uptake of pesticides and nutrients (O), sorption of pesticides and nutrients $(6)$, and degradation and transformation of pesticides and nutrients (O). Several feedbacks exist between these processes resulting in the interrelation of the processes involved in catchment hydrology, biodiversity, and pollutant fate

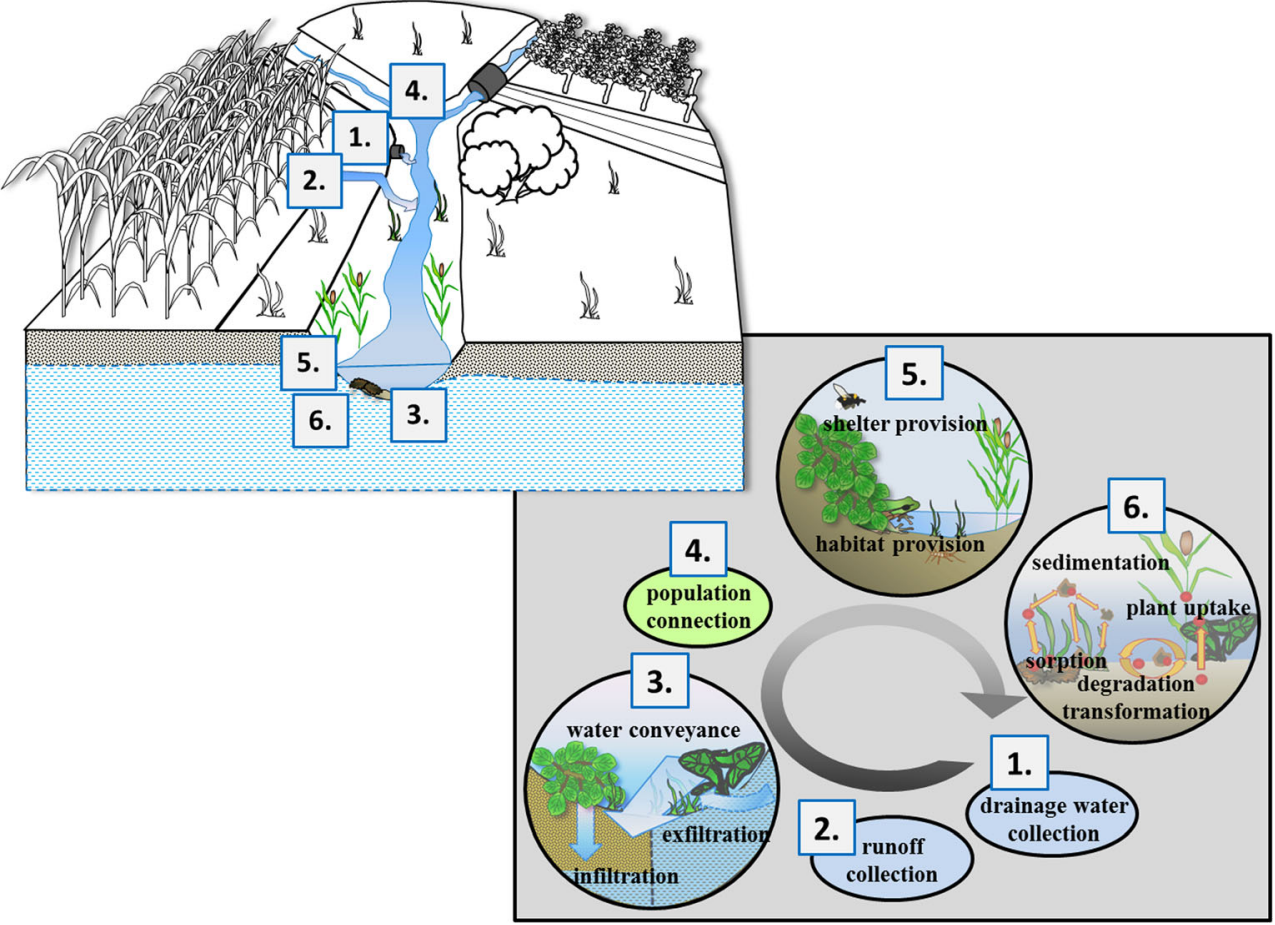

Moussa et al. 2002; Vaughan et al. 2008). For example, Marofi (1999) measured saturated hydraulic conductivities ranging 20 to $600 \mathrm{~mm} \mathrm{~h}^{-1}$ in ditch beds in a catchment in southern France.

The collected water fluxes are routed downstream by the ditches toward catchment outlets and receiving water bodies. The downstream transfer is regulated by the ditch hydraulic behavior and thus depends on several characteristics, including the ditch shape and morphology, i.e., length, cross section, slope, bed, or sidewall roughness (Scholz and Trepel 2004), and upstream or downstream reach connections, such as confluence, piped sections, etc. (Nédélec and Gay 2008). Friction mechanisms that are induced by bed shape and roughness may significantly slow the water flow (Boutron et al. 2011; Hösl et al. 2012; Jarvela 2002; Kröger et al. 2009; Wu et al. 1999). Methods to design a single ditch or open-channel cross section in order to minimize roughness have been proposed by Das (2007) and Nourani et al. (2009). The hydraulic roughness that expresses these friction processes is often described by the synthetic Strickler coefficient. Based on the available Strickler coefficient databases, Lagacherie et al. (2006) highlighted a very high variability of roughness throughout a ditch network even within a small catchment. The values varied from $15 \mathrm{~m}^{1 / 3} \mathrm{~s}^{-1}$ for highly vegetated ditches to $50 \mathrm{~m}^{1 / 3} \mathrm{~s}^{-1}$ for dredged ditches with a permanent hydraulic regime. Crabit et al. (2011) empirically estimated smaller values, 3 to $11 \mathrm{~m}^{1 / 3} \mathrm{~s}^{-1}$, for highly vegetated ditches. These authors explained this difference by both the vegetation type, which was bushy non-aquatic and poorly flexible, and the low water level compared to the vegetation heights, which violates the theoretical assumptions behind the usual empirical hydraulic laws. In vegetated ditches, vegetation is the main source of roughness (Wu et al. 1999) and always increases the hydraulic retention time compared to non- or less-vegetated surfaces (Hösl et al. 2012; Kröger et al. 2009; Rhoads and Massey 2012). Roughness varies with the resistance and flexibility of plants, the blockage factor that is linked to the vegetation density (Nepf 2012), and the water level compared to vegetation height or roughness height of the ditch bed (Boutron et al. 2011; Jarvela 2005, 2002; Nepf 2012; Wu et al. 1999).

In sum, waterlogging control benefits crop production especially in lowland wet areas. Its optimization relies on a maximized surface runoff and subsurface water collection as well as rapid downstream conveyance of these fluxes. This can generally be achieved when the density of ditches in the network is high and the reaches poorly vegetated, poorly branched, large and deep, which improves the ditch hydraulic capacities.

\subsection{Soil erosion prevention}

Ditch networks play a key role in the prevention of soil erosion by surface runoff in agricultural plots. The prevention of soil erosion by water consists of limiting the erodibility of the field soils and reducing the intensity of surface runoff, which is a major factor of the detachment and transport of particles. Ditches, which are located on field margins, only play a role in surface runoff reduction. The settlement of terraces with associated ditches located downslope or ditches perpendicular to the slope direction is typical land conservation techniques 
(Gallart et al. 1994). The combination of terraces and ditches decreases the length over which overland flow occurs along the catchment slope. Thereby, the flow amount and velocity throughout plots are limited, as well as its ability to dislodge and transport soil particles (Galea and Ramez 1995; Gallart et al. 1994). Ditches are usually used to decrease the slope length throughout plots by intercepting and channelizing the runoff waters (Dunn and Mackay 1996; Levavasseur et al. 2012). Especially, ditches intercept and channelize runoff fluxes exiting the plots and avoid their propagation and acceleration along other plots located downslope (Dunn and Mackay 1996; Levavasseur et al. 2012). The factors and characteristics of ditches that influence the interception and channeling of surface runoff were already described in Sect. 3.1.

In sum, soil erosion prevention by capturing overland flow evidently benefits crop production whether on short or long term. This ecosystem service is particularly valued in hilly agricultural landscapes submitted to high-intensity rainfall events. As for waterlogging control, its optimization relies on the maximization of surface runoff and subsurface water collection as well as rapid downstream conveyance. This is generally achieved when the density of ditches in the network is high and the reaches poorly vegetated, poorly branched, large and deep.

\subsection{Groundwater recharge}

As for any stream, ditches are prone to recharge groundwater when the groundwater table is below the water level in the ditch. However, this recharge may be limited by the low infiltration area offered by ditches compared to plot areas (Flint et al. 2002). Nevertheless, during periods of low water table after drought, the groundwater recharge can be very important as, for example, the case of intermittent rivers in semi-arid and arid areas (Crerar et al. 1988; Hughes and Sami 1992). Dages et al. (2009) observed that, despite representing only $6 \%$ of a Mediterranean catchment area, groundwater recharge by infiltration from the ditch network can represent up to $50 \%$ of the total groundwater recharge during autumnal rain events following a dry period. Of course, groundwater recharge from ditches is unlikely to be substantial in lowlands with perennial shallow groundwater.

Ground water recharge basically results from an efficient surface runoff capture and its maximized infiltration during slow downstream conveyance (Table 1). The conditions for an optimal runoff collection and reduced downstream conveyance have been described in Sect. 3.1. The conditions for preferential infiltration zones are found, especially in landscapes that are characterized by periods of droughts and ditches with low flows and/or ephemeral flows, such as in arid or semi-arid climates (Abu-Taleb 1999; Dages et al. 2009; Sorman et al. 1997). The infiltrating periods may undergo time-dependent variations. These variations may either be punctual, occurring at the flood event scale, or seasonal, depending on the climate (Blann et al. 2009; Koivusalo et al. 2008; Loumagne and Tallec 2013). Debieche et al. (2006), for example, observed that infiltration periods were very short and were restricted to the dry season in a French catchment under humid oceanic climate. In contrast, under less humid climates, the infiltrating periods within ditches may undergo more variation (Girard et al. 2011), as evidenced by Marofi (1999) in a Mediterranean catchment. The infiltration and exfiltration periods could alternate in the same ditch within a few hours during heavy autumnal rainfall events due to the rapid fluctuation of the groundwater levels. Moreover, infiltration occurred in some reaches of the network, whereas exfiltration occurred in others.

The intensity of the infiltration process depends on both the hydraulic gradient between the ditch and the water table level and the hydraulic properties of the ditch sidewalls and bed materials. It is important to notice that the latter properties are often not well known and are therefore generally calibrated as an exchange coefficient in hydrological modeling approaches (Carluer and Marsily 2004; Moussa et al. 2002; VanderKwaak 1999). The hydraulic conductivity gives an estimation of the potential intensity of infiltration fluxes. The hydraulic conductivity values of ditch beds and sidewalls vary throughout ditch networks as already mentioned in Sect. 3.1.

In sum, the contribution of ditches to groundwater recharge may be substantial according to the hydrological conditions prevailing locally. Accordingly, ditches were described to be preferential zones of groundwater recharge in semi-arid areas. Groundwater recharge optimization relies on an efficient surface runoff collection and a maximal infiltration allowed by a slow downstream conveyance. This is generally achieved for high-density networks where the reaches are highly branched, vegetated, perpendicular to the slope, large and deep, and if no litter or fine sediment layer seals the ditch bed porosity.

\subsection{Flood regulation}

Primarily designed to favor waterlogging limitation and soil erosion control, ditches improve the hydraulic connectivity between uphill areas and the outlet. As a consequence, they generally induce a higher peak discharge, a lower lag time, and a higher flow volume at the catchment outlets (Buchanan et al. 2012; Carluer and de Marsily 2004; Moussa et al. 2002), increasing the flood hazard intensity downstream. For example, by simulation, Moussa et al. (2002) quantified an increase of 9 to $43 \%$ of the peak flow due to the presence of a manmade ditch network. However, under particular conditions, ditch networks may also reduce flood hazards by reducing the peak discharge and increasing the lag time (Loumagne and Tallec 2013). This is achieved, on the contrary to natural hydrographic networks, when ditches are densely vegetated 
and designed with gentle slopes or when ditch networks are highly branched and sinuous (Levavasseur et al. 2012). Indeed, this slows down the conveyance velocity and lengthens the transfer distances. Flood attenuation should thereby favored when surface runoff and subsurface water collection are minimal, the downstream conveyance reduced, and the infiltration maximized (Table 1).

The equipment of ditch networks with hydraulic structures (e.g., buried pipes and weirs) that improve water storage capacity of the network (Acreman et al. 2007; Sofia et al. 2014) may attenuate floods downstream during extreme rain events. Equipped ditch networks are considered as one of the techniques permitting dynamic flood retention (Poulard et al. 2008). The hydraulic structures of ditch networks act as charged structures with open gates during extreme events. The ditches located upstream of these structures display improved water storage capacity. Diminish flood risk downstream in urbanized floodplains with dynamic flood retention techniques requires increasing the uphill water storage in ditches and groundwater.

In sum, an adequate dimensioning of ditch networks can attenuate floods. The attenuation effect is optimal when ditch networks are highly vegetated (Carluer and Gascuel 2011), highly branched across slopes (Levavasseur et al. 2012), and equipped with hydraulic structures such as weirs.

\subsection{Water purification}

Ditches connect agricultural fields and streams and may thus rapidly carry diffuse agricultural pollutions, including sediments, nutrient, and pesticides, to downstream receiving water bodies. Moreover, infiltration processes reducing the pollutant loads in flowing water (Carluer and Marsily 2004) may generate groundwater contamination (Burkat et al. 1999; Delin and Landon 2002; Field et al. 2003). Ditches, however, also hold inherent pollutant retention capacities that confer upon ditches substantial water purification power. Ditches may thus constitute pathways favoring both pollutant propagation toward water bodies and efficient buffer zones toward diffuse agricultural pollution.

\subsubsection{Ditch networks: pollutant collectors and propagation pathways}

Sediment fluxes reaching ditches via overland flow are directly related to runoff generation and erosion mechanisms on upstream plots (Tucker and Bras 1998). These sediment fluxes can be modulated when crossing ditch margins. If gullies are connecting the adjacent field and the ditch, the sediment loads in the overland flow can reach very high concentrations (Lecce et al. 2006; Tucker and Bras 1998). However, if ditches are connected to the adjacent fields by intact grass strips, the sediment loads may be consistently attenuated before reaching the ditch (Gumiere et al. 2011; Huang et al. 2002; Tucker and Bras 1998). Sidewall erosion is deemed to be a minor source of suspended sediments that are transported throughout vegetated ditches (Lecce et al. 2006). However, it has been punctually observed for substantial flood events occurring after maintenance operations (Levavasseur et al. 2014).

The nutrient inputs to ditches are intimately related to surface runoff and subsurface water collection (see Sect. 3.1) (Edwards and Withers 2008; Kröger et al. 2008). Nutrient inputs are closely related to the ditch network design, especially the ditch density. Zhang et al. (2013), for example, observed that the higher the ditch density is, the higher the nitrogen fluxes entering ditches are. Approximately $90 \%$ of the inorganic $\mathrm{P}$ is exported by runoff fluxes, whereas 70 to $90 \%$ of inorganic $\mathrm{N}$ is exported by tile drainage (Edwards and Withers 2008; Kröger et al. 2008, 2007a). In surface runoff water, consequent variations in the nutrient loads have been attributed to a seasonal factor but are also potentially impacted by the rainfall intensity, cropping system, and vegetation cover of the upstream fields (Edwards and Withers 2008; Kröger et al. 2008). Accordingly, nutrient input to ditches via runoff collection mainly occurs during the winter and spring (Edwards and Withers 2008; Kröger et al. 2008) in temperate climates. In runoff fluxes, nitrogen is essentially dissolved, whereas dissolved phosphorus represents only 25 to $50 \%$ of the total inorganic P (Edwards and Withers 2008; Nguyen and Sukias 2002).

Pesticides may attain ditches associated with runoff fluxes and drainage water that are collected by ditches (see Sect. 3.1) or by drift deposition or direct application during ditch maintenance. At the annual scale, the cumulated pesticide load in runoff water that is collected by ditches can reach up to $6 \%$ of the dose that is sprayed on adjacent fields (Louchart et al. 2001; Tang et al. 2012). For example, this has been observed for the herbicides diuron, simazine, and metolachlor when applied to vineyards (Louchart et al. 2001; Tang et al. 2012). The yearly cumulated amount of pesticides that leach on crop plots and that reach ditches via tile drains is generally approximately $<0.1$ to $1 \%$ of the dose that is sprayed on adjacent plots but can occasionally reach up to $4 \%$ under significant macropore flow in the soil (Garon-Boucher 2003; Tang et al. 2012; Voltz and Louchart 2001). Drift deposition may be a punctual but intense input of pesticides to ditches, potentially amounting to 10 to $50 \%$ of the pesticide load that is annually sprayed on surrounding plots (Garon-Boucher 2003; Tang et al. 2012).

The capture of surface runoff and subsurface water and their associated pollutant loads negatively affects water quality downstream. Indeed, the rapid water conveyance contributes to the degradation of the downstream water bodies' quality (Branger 2003; Kao et al. 2002; Louchart et al. 2001). It can however be compensated if the pollutants are retained in the ditch during their transport and if infiltration fluxes are 
substantial, which may decrease the pollutant loads in the water column within ditches. Of course, pollutant leaching will contribute to groundwater contamination (Dousset et al. 2010). However, several processes contribute to the retention of pollutants within ditches. The water purification power of ditches is optimal when the downstream conveyance is reduced and when the processes involved in their retention are maximized (Table 1). These processes and the pedoclimatic context or ditch characteristics modulating their occurrence and intensity are described hereafter for successively sediments, nutrients, and pesticides.

\subsubsection{Sediment retention in ditches}

Some ditches may efficiently trap sediments. Lecce et al. (2006) determined that the mean sediment retention capacity of ditches ranged from 8.6 to $107.2 \mathrm{~kg} \mathrm{~m}^{-1}$ year $^{-1}$, generating sediment trapping of $1366 \mathrm{Mg}$ year $^{-1}$ in a $7.7-\mathrm{km}^{2}$ catchment in North Carolina, USA. In the latter catchment, the sedimentation conditions are favored by gentle slopes ranging from 1 to $4 \%$ (Lecce et al. 2006). Moreover, Flora and Kröger (2014) measured the total suspended solid removal in vegetated ditches that were equipped or not by consecutive weirs, ranging from 72 to $94 \%$.

Within the ditches, sediment retention is mainly due to sedimentation processes or to the infiltration of particleloaded water fluxes and, more marginally, to the sieving of particles by vegetation and litter (Fiener and Auerswald 2003; Liu et al. 2008). The sieving of sediments through vegetation and litter is negligible because the pore size of these substrates is generally greater than the particle diameter (Fiener and Auerswald 2003).

Sedimentation is effective for sand- to medium-silt-grainsized particles ( $>40-60-\mu \mathrm{m}$ diameter), which are characterized by relatively high settling velocities, whereas clay size particles have too low mass densities to undergo settling by gravity for current flow velocities (Fiener and Auerswald 2003; Liu et al. 2008). As reviewed by Liu et al. (2008), the characteristics affecting sedimentation in grassed water ways include vegetation cover, water level, and morphology, i.e., slope, width, and length. We assumed that similar characteristics influence sedimentation within ditches. As mentioned above, vegetation generates friction and roughness, which decrease the flow velocity and enhance the sedimentation potential (Fiener and Auerswald 2003; Gumiere et al. 2011; Hösl et al. 2012; Needelman et al. 2007), which has been evidenced by Moore et al. (2010), who detected a lower proportion of suspended solids in the water column of a vegetated ditch than those in the water column of a non-vegetated ditch. The ditch morphology and the water level fluctuations also influence the flow velocity (Liu et al. 2008).

Sediments may also be efficiently removed from the water column via the infiltration of loaded runoff water (Fiener and
Auerswald 2003; Liu et al. 2008). Clay-sized particles, which tend to stay in suspension in the water column, are predominantly removed by infiltration (Fiener and Auerswald 2003). Infiltration is driven by both the vegetation cover, which, by reducing the flow velocity, enhances the potential infiltration time, and the ditch soil characteristics, namely, its porous structure (Fiener and Auerswald 2003; Gumiere et al. 2011; Hösl et al. 2012; Liu et al. 2008; Needelman et al. 2007).

General models exist that simulate the sedimentation and remobilization of particles and pollutants within streams and channels according to general physical laws (Merritt et al. 2003; Förstner et al. 2004; Westrich and Förstner 2007; Belaud and Baume 2002). There is not, however, any model specific to ditch networks, which allow quantifying the respective contribution of these processes to the global retention efficiency.

In sum, the sediment retention power of ditches is optimal when sedimentation, sieving, and infiltration processes are maximized. This is generally observed when ditch networks are highly vegetated and branched and equipped with hydraulic structures such as weirs. Large ditches with gentle slope and porous bed substratum generally increase the sediment retention power.

\subsubsection{Nutrient retention in ditches}

The nutrient retention power of ditches has been reported to vary greatly between 3 and $92 \%$. Table 2 synthesizes the measured nutrient retention efficiencies of several vegetated and non-vegetated ditches. The retention of phosphorus and total nitrogen was reported to be higher on average than that of nitrates or ammonium. But, no clear positive influence of dense vegetation can be detected which suggest that a large part of the observed variation of retention is hidden by differences in the local conditions of the studied ditches. In fact, nutrient retention relies on several processes namely sorption, transformation, plant uptake, or sedimentation of loaded particles. The nutrient removal efficiency of ditches varies according to the intensity of the mentioned processes. The ditch characteristics influencing the occurrence and intensity of these processes are described hereafter.

Sorption processes may lead to some retention of inorganic $\mathrm{P}$ within ditches, which should not be the case for inorganic $\mathrm{N}$. The sorption of P mainly occurs onto ditch sediments (Needelman et al. 2007; Nguyen and Sukias 2002). The iron-humic acid and aluminum-humic acid complexes play a key role in P sorption on ditch sediments (Nguyen and Sukias 2002). The $P$ sorption to iron-humic acid complexes is characterized by low-energy bonds, whereas $\mathrm{P}$ is sorbed to aluminum-humic acid complexes by high-energy bonds (Neal and Heathwaite 2005). The P retention capacity of ditch sediments and the potential desorption of $\mathrm{P}$ are thus impacted by the relative proportion of iron and aluminum hydroxides. $\mathrm{P}$ sorption to sediments is proportional to the grain size, with 
greater sorption occurring on fine particles (Nguyen and Sukias 2002). Fine particles are preferentially transported throughout ditches, which could lower the retention capacity of sediments (Nguyen and Sukias 2002). These sorption processes are greatly impacted by hydrochemistry, particularly by the redox potential and $\mathrm{pH}$ (Nguyen and Sukias 2002; Smith and Pappas 2007). Sediments can thus alternatively be sources and sinks of $\mathrm{P}$ depending on the hydrochemistry and sediment characteristics (Smith and Pappas 2007).

Particulate-bound nutrient, especially phosphorus, may also be subtracted from the water column by sedimentation (Liu et al. 2008). As previously described, the ditch characteristics influencing sedimentation include vegetative cover, water height, and ditch morphology (see Sect. 3.5.2).

Plant uptake can be a significant sink of nutrient in ditches. Wetland plants generally assimilate $5 \%$ of the nutrient fluxes (Kröger et al. 2007b). The amount of nutrient that is assimilated by vegetation is related to the concentration in the water phase. In case of high nutrient concentrations, wetland plants assimilate a greater amount of $\mathrm{N}$ and P (Kröger et al. 2007b), which was observed by Kröger et al. (2007a, b) in a vegetated ditch in which the increase in nutrient concentration in water led to an additional uptake of 2 and $7 \mathrm{mg} \mathrm{g}^{-1}$ plant for $\mathrm{P}$ and $\mathrm{N}$, respectively. The plant uptake of nutrient is, however, subjected to strong seasonal variation because it is intimately related to vegetation growth (Kröger et al. 2008, 2007b). Moreover, previously assimilated nutrients may be released after plant senescence during the dormant season (Kröger et al. 2007b).

The decrease in the $\mathrm{N}^{-} \mathrm{NO}_{3}{ }^{-}$concentrations within ditches mainly results from biological processes, whereas the decrease in the $\mathrm{N}^{-\mathrm{NH}_{4}}{ }_{4}^{+}$and $\mathrm{P}$ concentrations is assumed to be due to physicochemical processes (Smith and Pappas 2007). The evaluation of the relative importance of each process is difficult especially for $\mathrm{N}$. Indeed, the major $\mathrm{N}$ species $\mathrm{N}$ $\mathrm{NO}_{3}{ }^{-}, \mathrm{N}-\mathrm{NH}_{4}{ }^{+}$, and $\mathrm{N}-\mathrm{NO}_{2}{ }^{-}$undergo complex and simultaneous interactions resulting from nitrification, denitrification, and assimilation processes (Kröger et al. 2007a). The provision of habitats to microbial and vegetal species within ditches positively affects nutrient retention. Indeed, these species use nutrient for their development and growth.

In sum, the nutrient retention capacity of ditches can vary largely, from 3 to $92 \%$ according to local conditions. It is optimal when sorption, sedimentation, transformation, and plant uptake are maximized. Which of these processes are the most important for retention has not been studied in details. Given their simultaneous and feedback actions, the link between these processes and general ditch characteristics is tedious. However, they all depend on the vegetation cover density. Highly vegetated ditches are generally most prone to reduce nutrient loads.

\subsubsection{Pesticide retention in ditches}

The pesticide retention power of ditches has also been observed to vary greatly between 3 and $99 \%$. Table 3 synthesizes the measured pesticide retention efficiencies and associated ditch characteristics. The retention efficiency generally increases with increasing hydrophobicity of the molecules. The pesticide molecules are classified from top to bottom by decreasing hydrophobicity in Table 3. Qualitative evaluation of pesticide retention by mean of retention indices has been proposed by Margoum et al. (2003):

$I_{\mathrm{R}}($ Retention Index $)=a . \mathrm{S}+b . \mathrm{LV}+c . \mathrm{DV}$

with $\mathrm{S}, \mathrm{LV}$, and DV being the relative cover (\% of surface area) of sediments (S), living vegetation (LV), and dead vegetation (DV) and $a, b$, and $c$, being a dimensional coefficients describing the relative sorption power of sediments, living vegetation, and dead vegetation, respectively set to 1,2 , and 40 (Garon-Boucher 2003; Margoum et al. 2003). The retention capacity of ditches as estimated by these indices may differ from observations and experimental results (Margoum et al. 2003; Stehle et al. 2011). Levavasseur (2012) thus proposed the effective pesticide retention capacity (EPRC) index modulating the $I_{\mathrm{R}}$ indices by the flow velocity.

Pesticide retention within ditches mainly results not only from sorption processes (Elsaesser et al. 2013; Stehle et al. 2011) but also from the processes of degradation, plant uptake, or sedimentation of loaded particles. The ditch characteristics influencing the occurrence and intensity of these processes are described hereafter.

Sorption processes are deemed to be the main mechanisms of pesticide retention buffering both surface and leaching fluxes within ditches (Dousset et al. 2010; Elsaesser et al. 2013; Stehle et al. 2011). Indeed, several components of ditches, including soil, sediments, vegetation, and litter, can provide efficient sorption sites for pesticides (Lagacherie et al. 2006; Margoum et al. 2006; Vallée et al. 2014; Wan et al. 2006). The relative efficiency of these sorption substrates, which is represented by the sorption coefficient $\left(K_{\mathrm{f}}\right)$, varies among pesticides. Figure 3 compiles the mean $K_{\mathrm{f}}$ values for various pesticides, fitted from sorption experiments on wetland plants, ditch sediments, and litter (Crum et al. 1999; Garon-Boucher 2003; Gebremariam et al. 2012; Passeport et al. 2011a; Vallée et al. 2014).

Organic matter, especially humified organic matter, provides preferential sorption sites for pesticides (Margoum et al. 2003; Vallée et al. 2014), which could explain the very high sorption coefficients that are measured in vegetation and most of all litter (Fig. 3). However, factors other than organic matter may influence the sorption mechanisms of pesticides (Vallée et al. 2014). The sorption mechanisms of polar or 
Table 2 Nutrient mitigation power of ditches

\begin{tabular}{|c|c|c|c|}
\hline Nutrient & Ditch type & Mitigation (\%) & References \\
\hline \multirow[t]{3}{*}{$\mathrm{N}^{-\mathrm{NO}_{3}}{ }^{-}$} & Vegetated & 3.16 & Moore et al. (2010) \\
\hline & Vegetated & 7 to 23 & Smith and Pappas (2007) \\
\hline & Non-vegetated & 3.37 & Moore et al. (2010) \\
\hline \multirow[t]{2}{*}{$\mathrm{N}-\mathrm{NH}_{4}^{+}$} & Vegetated & 11.7 & Moore et al. (2010) \\
\hline & Non-vegetated & 19 & Moore et al. (2010) \\
\hline \multirow[t]{3}{*}{ Total nitrogen } & Vegetated & 92 & Moore et al. (2010) \\
\hline & & 57 & Kröger et al. (2007a) \\
\hline & Non-vegetated & 77 & Moore et al. (2010) \\
\hline \multirow[t]{4}{*}{ Phosphorus } & Vegetated & 36 & Moore et al. (2010) \\
\hline & & 43.9 & Kröger et al. (2008) \\
\hline & & 63 to 74 & Smith and Pappas (2007) \\
\hline & Non-vegetated & 71 & Moore et al. (2010) \\
\hline
\end{tabular}

Ditches and especially vegetated ditches hold inherent nutrient mitigation power. The reduction in nutrient loads along a ditch reach varies from 3 to $92 \%$ depending on the nutrient considered and the characteristics of ditches. Total nitrogen and phosphorus are preferentially reduced along ditches with regard to nitrates and ammonium polarizable pesticides are highly related to the $\mathrm{pH}$, the clay content of sediments, and the cation exchange capacity (CEC) (Brown et al. 2004; Ulén et al. 2013; Vallée et al. 2014). Furthermore, at the ditch scale, the chemical retention time expressing the potential pesticide-substrate contact time, the water level, and ditch bottom shape significantly impact all of the sorption processes (Boutron et al. 2011; Elsaesser et al. 2013; Garon-Boucher 2003; Stehle et al. 2011).

Sedimentation of pesticide-loaded particles may also contribute to pesticide retention, which is potentially the case of hydrophobic pesticides that are likely to be preferentially adsorbed and transported by suspended particles. For example, Budd et al. (2009) measured the proportions of pyrethrin associated to the particulate phase to be 62 to $93 \%$ of the total pyrethrin in the water column in a vegetated ditch. Accordingly, Budd et al. (2009) suggest that the sedimentation of these loaded particles could lead to an important decrease in pyrethrin concentrations. As previously described, the ditch characteristics influencing sedimentation include vegetative cover, water level, and ditch morphology (see Sect. 3.5.2).

Plant uptake may also contribute to dissolved pesticide retention within ditches (Branger 2003). High proportion of pesticides, linuron, pyrethrin, chlorpyrifos, or carbaryl has been detected in plants that are grown in ditches, but the distinction between adsorption and absorption (plant uptake) was rarely evidenced (Bennett et al. 2005; Crum et al. 1997; Garcinuño et al. 2006; Kröger et al. 2009; Moore et al. 2011).

Biotic and abiotic degradation processes are also involved in pesticide retention within ditches, which has been observed in several studies. Moreover, shorter half-lives (DT50) of pesticides were observed in ditches than in sediments or in water and varied between 7 and 12 days for linuron, approximately 1 day for cyhalothrin and 10 days for imidacloprid in vegetated ditches (Crum et al. 1997; Mahabali and Spanoghe 2014). In contrast, these half-lives are reported in the Agritox database (ANSES 2014) as 46, 22 to 83, and 30 days in sediments and 48,3 , and 129 days in water, for linuron, cyhalothrin, and imidacloprid, respectively. Further evidence of pesticide degradation in ditches was provided by Bennet et al. (2005) who detected the metabolites of pyrethrin in ditches. A detailed study of the degradation potentials within ditches has not been performed. However, it was suggested that pesticide biodegradation depends primarily on biofilms that develop on vegetation and sediments (Needelman et al. 2007) and can be favored by an increase in the hydraulic retention time (Liu et al. 2012).

Although some significant work has been performed to study the sorption processes in ditches, sorption kinetics in ditches still need to be investigated in order to be able to relate quantitatively to the variable hydraulic conditions (flow rates, water levels, and substrate permeabilities) prevailing in ditches. Similarly, the factors controlling the degradation potentials of pesticides within ditches need to be thoroughly investigated for prediction according to the ditch characteristics. Moreover, pesticide leaching processes within ditches located in highland areas need to be examined.

In sum, the pesticide retention efficiency of ditches varies largely according to local conditions, between 3 and $99 \%$. The pesticide retention is predominantly controlled by sorption processes and, to a lesser extent, by sedimentation, degradation, and plant uptake. As for nutrients, pesticide retention is optimal when sorption, sedimentation, degradation, and plant uptake are maximized. This principally relies not only on the vegetation cover density but also on sediment texture and litter properties. Highly vegetated ditches with thick litter layer and fine sediment texture are more prone to reduce pesticide loads. 
Table 3 Pesticide mitigation power of ditches

\begin{tabular}{|c|c|c|c|c|c|c|}
\hline Molecule & $\begin{array}{l}\text { Reach length } \\
\text { (m) }\end{array}$ & Substrate characteristics & $\begin{array}{l}\text { Vegetation } \\
\text { cover }(\%)\end{array}$ & $\begin{array}{l}\text { Hydraulic retention } \\
\text { time }(\mathrm{h})\end{array}$ & Mitigation (\%) & References \\
\hline$\lambda$-Cyhalothrin & 650 & nd & 88 & 6.0 & 98.8 & Bennett et al. (2005) \\
\hline Bifenthrin & 650 & nd & 88 & 6.0 & 96.1 & Bennett et al. (2005) \\
\hline Permethrin & 389 & $\begin{array}{l}21: 35: 44 \text { (\% sand/silt/clay) } \\
0.6 \% \text { OC }\end{array}$ & 100 & nd & 44 & Moore et al. (2011) \\
\hline \multirow[t]{2}{*}{ Chlorpyrifos } & 402 & \multirow{2}{*}{$\begin{array}{l}21: 35: 44(\% \text { sand } / \text { silt/clay }) \\
\quad 0.6 \% \text { OC }\end{array}$} & 100 & nd & 19 & Moore et al. (2011) \\
\hline & 200 & & $80-100$ & nd & 38 & Gill et al. (2008) \\
\hline \multirow[t]{4}{*}{ Diflufenicanil } & 50 & Mineral and organic matters & nd & nd & 16 & \multirow[t]{4}{*}{ Garon-Boucher (2003) } \\
\hline & 50 & Poorly vegetated, coarse sediments & nd & nd & 27 & \\
\hline & 25 & Vegetated, coarse sediments & nd & nd & 58 & \\
\hline & 100 & Vegetated, dead leaves & nd & nd & 58 & \\
\hline \multirow{5}{*}{$\begin{array}{l}\text { Indoxacarb } \\
\text { Trifloxystrobin } \\
\text { Thiacloprid }\end{array}$} & 44 & Loamy sand, oc $0.78 \%$ & 0 & 1.3 & 92 & \multirow[t]{5}{*}{ Elsaesser et al. (2013) } \\
\hline & & & 49 & & 97 & \\
\hline & & & 72 & & 97 & \\
\hline & & & 86 & & 97 & \\
\hline & & & 100 & & 97 & \\
\hline \multirow[t]{2}{*}{ Tebuconazole } & 44 & Loamy sand, oc $0.78 \%$ & $0-100$ & 1.3 & $92-97$ & Elsaesser et al. (2013) \\
\hline & 7.3 & Hemp fibers & nd & nd & $24-59$ & Boutron et al. (2011) \\
\hline \multirow[t]{5}{*}{ Diuron } & 7.3 & Hemp fibers & nd & nd & $26-48$ & Boutron et al. (2011) \\
\hline & 50 & Mineral and organic matters & nd & nd & 3 & \multirow[t]{4}{*}{ Garon-Boucher (2003) } \\
\hline & 50 & Poorly vegetated, coarse sediments & nd & nd & 24 & \\
\hline & 25 & Vegetated, coarse sediments & nd & nd & 64 & \\
\hline & 100 & Vegetated, dead leaves & nd & nd & 48 & \\
\hline \multirow[t]{5}{*}{ Isoproturon } & 7.3 & Hemp fibers & nd & nd & $11-45$ & Boutron et al. (2011) \\
\hline & 50 & Mineral and organic matters & nd & nd & 9 & \multirow[t]{4}{*}{ Garon-Boucher (2003) } \\
\hline & 50 & Poorly vegetated, coarse sediments & nd & nd & 16 & \\
\hline & 25 & Vegetated, coarse sediments & nd & nd & 56 & \\
\hline & 100 & Vegetated, dead leaves & nd & nd & 40 & \\
\hline
\end{tabular}

Ditches and especially vegetated ditches hold inherent pesticide retention power. The reduction in pesticide loads along a ditch reach varies from 3 to $99 \%$ depending on the pesticide considered and the characteristics of ditches. Pesticides are classified from top to bottom by decreasing hydrophobicity. The reduction of the more hydrophobic pesticide loads is generally higher than for the less hydrophobic ones, but this is conditioned by ditch characteristics

$n d$ missing data, $O C$ organic carbon

\subsection{Biodiversity conservation}

Herzon and Helenius (2008) previously reviewed the biodiversity issues that are associated with lowland drainage ditches. These authors underlined that drainage ditches host a wide diversity of species, including plants, invertebrates, insects, amphibians, birds, and mammals. The main benefits of ditches for biodiversity conservation are recalled hereafter and completed with later findings.

The relatively low water level within ditches provides ideal growth conditions for a large diversity of aquatic and wetland plants (Bellavance and Brisson 2010; Elsaesser et al. 2013; Twisk et al. 2003). Wetland plants in ditches are most likely residual marsh plant species that were present before the area has been drained (Herzon and Helenius 2008). Furthermore, in drainage ditches that are characterized by a rather perennial base flow, the invertebrate diversity has been reported to be higher than in small lakes and streams (Simon and Travis 2011; Verdonschot et al. 2011; Williams et al. 2004). The number of bird species can also double if ditches are present in cropped areas (Arnold 1983; Herzon and Helenius 2008; Marja and Herzon 2012). The increase in bird diversity, however, is more related to the presence of trees on ditch margins than to the inherent ditch characteristics (Arnold 1983; Marja and Herzon 2012). Moreover, ditch networks are one of the most frequent non-cropped networks in cultivated landscapes, thereby providing a key service of ecological corridors (Herzon and Helenius 2008). These corridors permit the movement of amphibians, mammals, or insects that would otherwise be restricted in hostile and intensively cropped areas (Herzon and Helenius 2008; Van Geert et al. 2010). Ditch networks may also connect fractionated populations and favor 


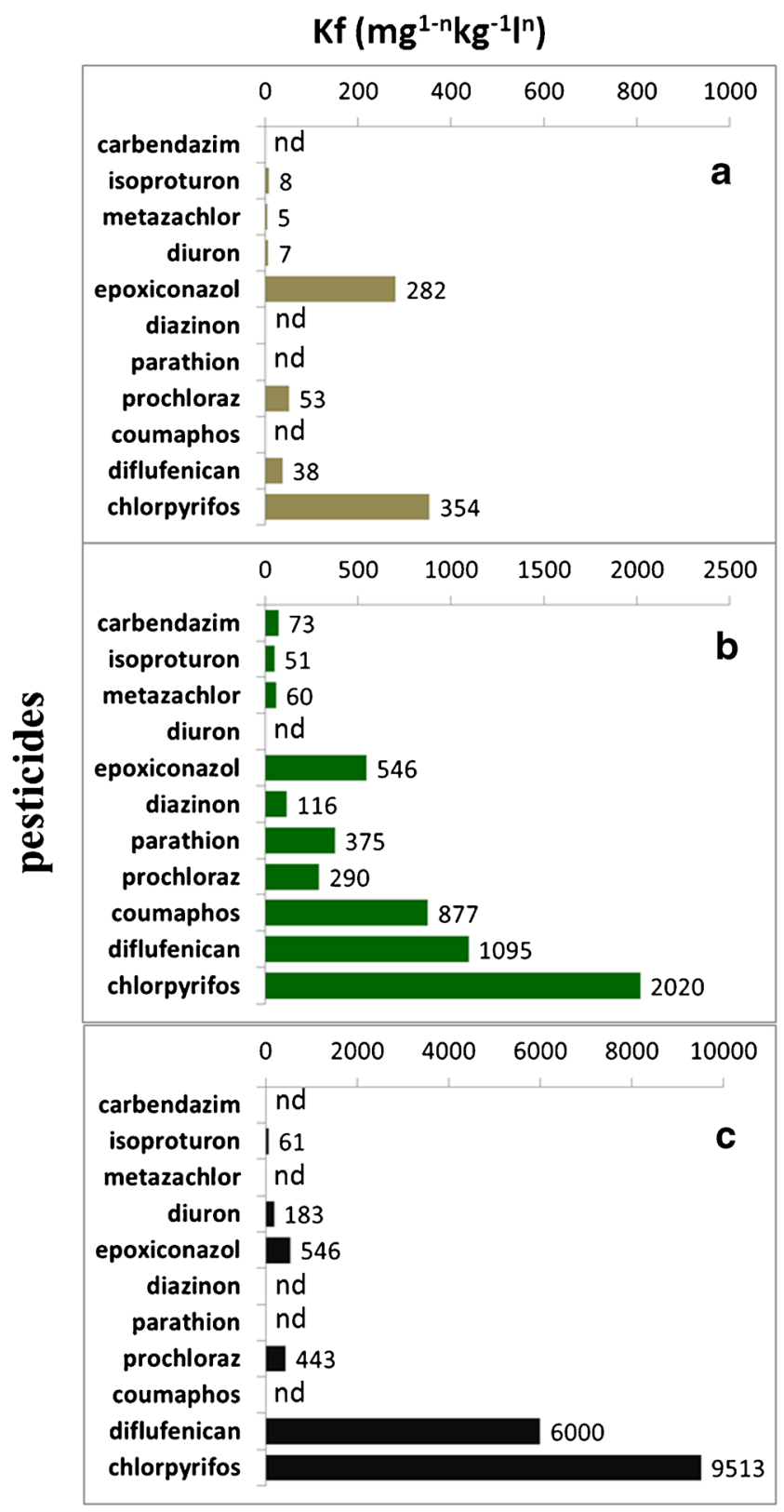

Fig. 3 Mean Freundlich sorption coefficients $\left(K_{\mathrm{f}}\right)$ indicating the affinity of the various pesticides for a sediments (in brown), b vegetation (in green), and $\mathbf{c}$ litter (in black). nd no data available in the literature. The pesticides are classified from top to bottom by increasing hydrophobicity. The various pesticides exhibit high affinity for ditch substrates especially for vegetation and litter. This affinity increases with increasing hydrophobicity

their survival and renewal. Indeed, habitat fractionation leads to plant and animal population isolation and threatens plant and animal long-term survival, especially for seed-setting plant species, which require insects for pollination (Van Geert et al. 2010). Van Geert and collaborators (2010) found that pollen dispersal was greater when plant populations were connected by ditches.

Ditches provide numerous microhabitat types, shelters, and connect populations. The biological functioning of ditches is conditioned by the water and pollutant fluxes. The collection of water fluxes allows maintaining a minimum water level along the network which is beneficial for a lot of species. Intense flows may, however, destroy habitats and shelters. Most of the processes tending to lower the pesticide and sediment loads benefit the biodiversity. This may not be the case for pesticide degradation, as metabolites are usually more toxic than the parent molecule. Nutrient fluxes stimulate the development of some plants and microbial communities but may also lead to eutrophication that may be harmful for other species.

The local hydrological catchment regimes induce more or less ephemeral flow within ditches, thereby controlling the fluctuation of soil humidity in the ditches. Drainage ditches are often regarded as wetlands (Flora and Kröger 2014; Kröger et al. 2008, 2009) in lowlands with temperate and humid climates. These ditches also present some physicochemical similarities with small lakes and streams (Verdonschot et al. 2011). Ditches are therefore unique ecosystems combining wetland and stream characteristics (Needelman et al. 2007). The ditch ecosystem, including beds, sidewalls, and margins, provides a stratification of microhabitats ranging from aquatic to wetland and terrestrial types (Marja and Herzon 2012). This stratification of habitat type depends on the vegetation cover (permanence and type) and on the water level fluctuations (Bellavance and Brisson 2010; Simon and Travis 2011; Twisk et al. 2003; Verdonschot et al. 2011; Williams et al. 2004).

The vegetation cover of ditches and margins provides efficient shelter for this biodiversity (Arnold 1983; Herzon and Helenius 2008; Marja and Herzon 2012). Moreover, the drying out of some ditches in the summer excludes the presence of predatory fishes and permits the development of frogs and newts (Herzon and Helenius 2008).

Ditch networks provide sheltered corridors, allowing the movement and connections of amphibian and insect populations (Herzon and Helenius 2008). Moreover, abundant exchanges with the surrounding terrestrial matrix may occur in these particular ecotones (Herzon and Helenius 2008). These exchanges, combined with the water flow conveyance capacity, confer upon ditches an important role in seed dispersal (van Dijk et al. 2014).

The characterization of the habitat stratification and shelter provision is lacking within irrigation ditches or ditches that are located in arid or semi-arid areas and prone to drastic fluctuations of the water level and the climatic conditions. This hinders the establishment of a relationship between ditch characteristics and biodiversity under various climatic contexts.

In sum, ditch networks constitute ecological corridors that play a key role in the conservation of biodiversity in intensively cropped landscapes. This ecosystem service is optimal when ditches offer diversified microhabitats and sheltered corridors. This is generally achieved within highly vegetated ditches with a relatively permanent base flow and low velocity of the water flow. 


\subsection{Intricacy and control factors of the ecosystem services provided by ditches}

As can be seen in Table 1, all of the ecosystem services that can be provided by ditches depend, to a certain extent, on the hydrological processes that take place within ditches. Moreover, most processes are involved in several services in a positive way for some of them and in a negative way for other (Table 1). Simultaneous maximization of all services that are potentially provided by ditches is therefore complex given the extensive feedbacks between processes. This maximization may even be unachievable in some instances and will most often require finding tradeoffs between different services. For example, maximizing the groundwater recharge will positively affect local and downstream surface water purification (sediment, nutrient, and pesticides) and the amount of groundwater resources but may also provide negative feedback to groundwater pollution (nutrient and pesticides). Finding adequate tradeoffs will certainly require fine tuning according to site-specific contexts of the processes in the ditches and of the ditch characteristics that control these processes.

All of the processes are individually driven by given ditch characteristics. Table 4 summarizes the ditch characteristics that have been previously shown as significantly influencing one or several processes. The main influent ditch characteristics include vegetative cover, ditch morphology (cross section, length, and slope), orientation with regard to the slope and location within the watershed, reach connections (piped sections, weirs, etc.), soil texture and structure, sediment and litter properties, biota and biofilms, and network topology. Some of these characteristics are fixed (e.g., orientation and connections) or slowly change with time (e.g., morphology), while others (e.g., vegetative cover and litter) are prone to drastic changes that are governed by current maintenance operations. Most of the ditch characteristics have a straightforward impact on only a few processes, whereas vegetation cover influences almost all of the processes (Table 4). However, given the intricacy of many processes, all of the ditch characteristics influence, to a certain extent, most processes. An accurate determination of ditch characteristics is therefore essential for understanding and predicting the functioning of ditches. In this respect, this review indicates several characteristics that are little known and/or weakly defined:

- The physical and hydraulic characteristics of the sidewalls and bed of the ditch.

- The variation in the vegetation characteristics of the ditches

- The sorption properties of pollutants for the variety of substrates that can be found in ditches, which is a prerequisite for identifying and possibly improving the sorption capacities of ditches.
Some ditch characteristics drastically evolve with ditch maintenance. Ditch maintenance may thereby constitute an efficient engineering tool to optimize given ecosystem services.

\section{Ditch maintenance: lever for the optimization of ecosystem services}

As previously described, the pedoclimatic context and intrinsic ditch characteristics impact the occurrence and intensity of the aforementioned processes and, consequently, the ecosystem services that are provided by ditches. Ditch maintenance is a key driver controlling the intrinsic ditch characteristics, such as vegetation nature and cover and bed soil texture and type, thereby controlling most of the processes. Ditch maintenance is therefore deemed to impact most widely ditch functioning and services. Hereafter, we address the influence of maintenance operations on ditch characteristics and on processes and services and then examine how maintenance may be used for optimizing ecosystem services.

Ditch design has been historically motivated by the necessity of strengthening the initial services, namely waterlogging limitation and water erosion control (Needelman et al. 2007; Zhang et al. 2013). Maintenance techniques were designed accordingly and aimed at regularly clearing vegetation and removing sediment (Kröger et al. 2009; Levavasseur et al. 2014; Needelman et al. 2007; Twisk et al. 2003). The main ditch maintenance operations include dredging, mowing, chemical weeding, and burning using manual or mechanized techniques (Fig. 1). Little is known about ditch maintenance design, i.e., the choice, the modality, and the succession of operation type and frequency in maintenance (Levavasseur et al. 2014). Depending on the pedoclimatic context, the dredging of drainage ditches has been reported to be performed once every 5 to 50 years (Levavasseur et al. 2014; Smith and Pappas 2007; Twisk et al. 2003), whereas operations leading to vegetation clearance, i.e., mowing, chemical weeding, or burning, are more frequently achieved a priori. In the Mediterranean context, these operations are performed at least once a year (Levavasseur et al. 2014). Often, maintenance strategies result from a combination in time of the four basic operations that were mentioned above (van Dijk et al. 2014; Levavasseur et al. 2014).

\subsection{Impact of maintenance operations on ditch characteristics}

The direct consequences of these operations on ditch characteristics or properties are threefold (Kröger et al. 2009; Needelman et al. 2007). The first consequence is the vegetation removal that is induced by all operations and, consequently, of the biota that are sheltered within the ditch. Vegetation 
Table 4 Main ditch characteristics influencing geochemical, geophysical, and biological processes within ditches

\begin{tabular}{|c|c|c|c|c|c|c|c|c|c|}
\hline \multirow[b]{2}{*}{ Processes } & & \multicolumn{8}{|c|}{ Ditch characteristics } \\
\hline & & $\begin{array}{l}\text { Vegetation } \\
\text { cover }\end{array}$ & $\begin{array}{l}\text { Reach } \\
\text { morphology }\end{array}$ & $\begin{array}{l}\text { Orientation } \\
\text { and location }\end{array}$ & $\begin{array}{l}\text { Soil texture } \\
\text { and structure }\end{array}$ & $\begin{array}{l}\text { Sediments } \\
\text { properties }\end{array}$ & $\begin{array}{l}\text { Litter } \\
\text { properties }\end{array}$ & $\begin{array}{l}\text { Biota and } \\
\text { biofilms }\end{array}$ & $\begin{array}{l}\text { Network topology } \\
\text { and reach connections }\end{array}$ \\
\hline \multirow[t]{4}{*}{ Hydrology } & $\begin{array}{l}\text { Subsurface water } \\
\text { collection }\end{array}$ & & $*$ & $*$ & $*$ & $*$ & & & \\
\hline & Runoff collection & & $*$ & $*$ & & & & & $*$ \\
\hline & Water conveyance & $*$ & $*$ & & & $*$ & & & $*$ \\
\hline & Infiltration & * & $*$ & & $*$ & $*$ & $*$ & & \\
\hline \multirow[t]{2}{*}{ Sediments } & Sedimentation & $*$ & $*$ & & & & & & \\
\hline & Remobilization & & & & & & & & \\
\hline \multirow[t]{3}{*}{ Pesticides } & Pesticide sorption & $*$ & & & * & $*$ & $*$ & & \\
\hline & Pesticide degradation & $*$ & & & & & & $*$ & \\
\hline & Plant uptake & $*$ & & & & & & & \\
\hline \multirow[t]{2}{*}{ Nutrients } & Nutrient sorption & * & & & & $*$ & & & \\
\hline & $\begin{array}{l}\text { Nutrient } \\
\text { transformation }\end{array}$ & * & & & & & & $*$ & \\
\hline \multirow[t]{3}{*}{ Biodiversity } & Habitat & $*$ & & & & & $*$ & & \\
\hline & Sheltering & * & & & & & $*$ & & \\
\hline & $\begin{array}{l}\text { Population } \\
\text { connection }\end{array}$ & $*$ & & & & & & & $*$ \\
\hline
\end{tabular}

Ditch characteristics influence most geochemical and geophysical and biological processes across agricultural landscapes. When boxes are unfilled, there is no known relation between the given ditch characteristics and the processes. Note that the vegetation cover influences most processes

*Influence of the given ditch characteristics on the given processes

removal may be completed with dredging, burning, and chemical weeding operations (Levavasseur et al. 2014) or partially completed with mowing and selective chemical weeding (Needelman et al. 2007). The second consequence is the modification of the properties of the ditch bed material after dredging, burning, and sometimes mowing. Dredging leads to the complete or partial removal of accumulated sediments within the ditch bed and of the biota that are sheltered within this layer. Ditch bed sediments have been reported to exhibit a finer texture with high silt and clay contents and higher organic matter content (Garon-Boucher 2003; Smith and Pappas 2007; Vaughan et al. 2008) before dredging than after. The permeability properties of ditch beds are therefore likely to be modified by dredging. To our knowledge, the effect on the soil properties of ditch burning has not been studied yet. Nevertheless, it has been demonstrated that after wildfire or field burning practices, the soil wettability (Bento-Gonçalves et al. 2012; DeBano 2000) and available organic matter content (González-Pérez et al. 2004; Yang and Sheng 2003a, b) are altered. If the mowed vegetation is not removed from ditches, it can considerably increase the litter layer and the available organic matter content of the ditch bed material (Lagacherie et al. 2006; Margoum et al. 2003, 2001). In a Mediterranean catchment, Levavasseur et al. (2014) observed an earlier and greater increase of litter in mowed ditches relative to the litter accumulation due to natural plant senescence during autumn and winter. The third consequence of maintenance is the modification of the shape of the ditch, which mainly concerns dredging and leads to the restoration of the volumetric storage capacity of the ditch.

In sum, all maintenance operations lead to vegetation clearance. Dredging and burning modify ditch bed and sidewall sediment properties including texture and organic matter content. Mowing may increase the litter layer if the moved vegetation is not removed. Dredging restores the morphology of ditches. The way maintenance operations affect ditch characteristics locally is generally well described. However, little is known about the impact of upstream maintenance on the downstream characteristics.

\subsection{Maintenance effect on the processes and services}

The change in the ditch characteristics resulting from maintenance operations will purposively modify the hydrological behavior of ditches and the transport and fate of solids and contaminants within the ditch as well as its functioning as ecosystem. The influence of ditch maintenance operations on processes is hereafter described and summarized in Table 5.

The vegetation clearance resulting from maintenance improves water conveyance within a reach and consequently decreases the hydraulic retention time (Kröger et al. 2009; 
Table 5 Effects of the maintenance operations on landscape processes

\begin{tabular}{|c|c|c|c|c|c|}
\hline \multirow[b]{2}{*}{ Processes } & & \multicolumn{4}{|c|}{ Maintenance operations } \\
\hline & & Dredging & Mowing & Chemical weeding & Burning \\
\hline \multirow[t]{4}{*}{ Hydrology } & Runoff collection & + & + & + & + \\
\hline & Subsurface water collection & ++ & 0 & 0 & - \\
\hline & Infiltration & $++/-$ & - & - & - \\
\hline & Water conveyance & +++ & ++ & ++ & ++ \\
\hline \multirow[t]{2}{*}{ Erosion } & Sedimentation & - & - & - & - \\
\hline & Transport and non-remobilization & $++/-$ & - & - & - \\
\hline \multirow[t]{3}{*}{ Pesticides } & Sorption & - & $+/-$ & - & $++/-$ \\
\hline & Degradation & -- & - & - & - \\
\hline & Plant uptake & -- & - & -- & - \\
\hline \multirow[t]{3}{*}{ Nutrients } & Sorption & - & 0 & 0 & 0 \\
\hline & Transformation & -- & 0 & - & - \\
\hline & Plant uptake & -- & - & - & - \\
\hline \multirow[t]{3}{*}{ Biodiversity } & Providing habitat & -- & - & -- & - \\
\hline & Providing shelter & -- & - & -- & - \\
\hline & Connecting populations & - & $+/-$ & - & - \\
\hline
\end{tabular}

The four basic maintenance operations, i.e., dredging, mowing, chemical weeding, and burning, impact most processes either in a positive or negative way. Note that the maintenance operations by modifying ditch characteristics influence either in a positive or negative way the geochemical, geophysical, and biological processes involved in the ecosystem services. There is no obvious optimal maintenance operation

+ positive effect of the maintenance operation on the given processes, - negative effect of the maintenance operation on the given processes, 0 no effect of the maintenance operation on the given processes
Liu et al. 2012). The increased water conveyance potential facilitates the rapid removal of excess water on cropped plots and limits the potential overflow of ditches, positively affecting waterlogging and erosion control (Levavasseur 2012). The increased water conveyance potential combined with a smaller hydraulic retention time may lead to decreased infiltration processes (Fiener and Auerswald 2003; Kröger et al. 2009; Lecce et al. 2006) and, in turn, to reduced groundwater recharge and increased downstream water flow. The latter impact on groundwater recharge, however, may vary according to the type of clearing technique. Dredging is known as the most efficient maintenance practice to restore the water conveyance function (Lecce et al. 2006). If properly achieved, dredging should also restore the permeability of the ditch bed and consequently enhance the exfiltration processes that are involved in farmed field drainage or infiltration processes that are involved in groundwater recharge. The specific impacts of ditch burning in addition to vegetation clearance have not been studied. However, because ditch burning modifies the soil wettability and soil organic matter content, it can be expected that infiltration or exfiltration will be modified.

At the same time, clearing vegetation in the ditches is likely to decrease the sediment trapping efficiency of the ditches (Fiener and Auerswald 2003; Kröger et al. 2009) by suppressing the filtration effect of the vegetation and by favoring more rapid flow velocities that limit sedimentation processes and enhance erosion processes. Mowing is, a priori, the operation with the smallest impact on the sediment trapping efficiency. Lecce et al. (2006) observed that during storms in the winter and spring, ditches export more sediments than during storms in the summer and autumn. On the catchment that these authors studied in North Carolina, the maintenance of ditches consisted of the mowing of vegetation from the ditch banks and bottom in late autumn or early winter. These authors therefore related the sediment trapping efficiency of ditches to the vegetation cover. The other maintenance operations, namely, chemical weeding, burning, and dredging, may have greater impacts on sediment retention. Levavasseur et al. (2014) observed that the chemical weeding of ditches in a French catchment resulted in almost no vegetation cover throughout the year. Accordingly, these chemically weeded ditches were very sensitive to ditch bank erosion during the intense rainfall events of autumn. Dredging, however, relocates sediments from the ditch to the adjacent fields, providing an important sediment sink for later runoff events. Burning produces new fine and non-cohesive particles that are, a priori, easily mobilized by subsequent flows and are therefore likely to deteriorate the quality of surface waters in terms of turbidity. The real impact of maintenance operations in terms of water turbidity for downstream water is uncertain.

The impact of maintenance operations on the contaminant transport and fate is most likely more complex because many processes are involved at different timescales. The higher pollutant retention capacity of vegetated compared to non- 
vegetated ditches has been demonstrated by specific case studies (Budd et al. 2009; Elsaesser et al. 2013, 2011; Moore et al. 2010). The involved mechanisms are not always completely clarified, and the hierarchy of processes leading to retention is generally not specified. The decrease in the hydraulic retention time and in the chemical retention time automatically leads to less time for the sorption, degradation, plant uptake, and sedimentation of loaded particles (Herzon and Helenius 2008; Kröger et al. 2009; Liu et al. 2012) and leaching processes. Kröger et al. (2009) estimated a chemical retention time that was three times higher for a vegetated ditch than for a geomorphologically similar, non-vegetated ditch. Vegetation and ditch sediments provide efficient retention sites for nutrients (Needelman et al. 2007; Smith and Pappas 2007) and pesticides (Gill et al. 2008; Margoum et al. 2003; Margoum et al. 2001; Pappas and Smith 2007). The removal of these sediments is therefore likely to reduce the retention capacity of the ditches. Dredging is most likely the most disturbing practice because it removes part of the sediments and the biota that are responsible for nutrient uptake and biotic pesticide degradation, as clearly shown for nutrients by Smith and Pappas (2007) and for pesticides by Pappas and Smith (2007), who observed a greater ability of the pre-dredged bed material to remove $\mathrm{N}^{-\mathrm{NO}_{3}}{ }^{-}, \mathrm{N}_{-} \mathrm{NH}_{4}{ }^{+}$, and soluble phosphorus compared to the bed material that was present after dredging. These authors also observed a greater release of soluble phosphorus from bed material after dredging. In contrast, dredging relocates nutrient that are trapped in vegetation and sediments to the adjacent fields, decreasing their potential release during the dormant season (Herzon and Helenius 2008). The same phenomena may occur for mowing when the mowed vegetation is removed (van Dijk et al. 2014). The effect of mowing without the removal of the vegetation requires further exploration. The induced increase in litter may provide new sorption sites for nutrients and pesticides. To our knowledge, the effect of burning on the pollutant retention potential of ditches has not yet been studied. We hypothesize that burning could lead to a significant release of nutrients that were previously trapped in plants. However, burned crop residues provide preferential sorption sites for pesticides as evidenced for diuron (Yang and Sheng 2003a, b) and clomazone (Xu et al. 2008). If present in a significant proportion and over a significant period, ashes may enhance the sorption properties. Apparently, this increase in sorption is associated with a decrease in pesticide degradation (Passeport et al. 2011b; Xu et al. 2008), but little is known regarding the desorption processes on ashes. Moreover, being a priori easily erodible, the fate of ashes needs to be studied. Finally, the dredging, chemical weeding, or mowing of drainage ditches is likely to contribute to downstream water contamination. Of all of the maintenance operations, little is known about their impact on desorption and leaching processes. Moreover, infiltrating ditches need to be studied because of the unknown effect of dredging on the infiltration intensity and groundwater recharge. If infiltration processes dominate, surface water contamination should be limited, but the risk of groundwater contamination increases. The characterization of the impact of burning on the pollutant retention capacity of ditches also requires specific investigation.

All of the maintenance operations clear the vegetation and thus potentially affect the biotic communities having their habitat, sheltered corridors, or food sources within ditches (Herzon and Helenius 2008). The intensity of the deterioration of the ditch ecosystem varies with the maintenance operation. Indeed, as observed by Levavasseur et al. (2014), chemically weeded ditches tend to have a reduced and scattered vegetation cover throughout the year. Dredging is expected to remove all of the fauna and flora from the upper layer of the ditch bed material (Smith and Pappas 2007; Pappas and Smith 2007). In contrast, periodic dredging can restore habitats for rare plant species, as it decreases eutrophication and limits light competition (Herzon and Helenius 2008). Mowing also can favor rare pioneer plant species for the same reasons (van Dijk et al. 2014; Leng et al. 2011) and has been described as an effective means of seed dispersal (Leng et al. 2011). Finally, because field burning has been used to enhance soil fertility and vegetation growth, this maintenance operation should favor rapid vegetation restoration.

In sum, there is no obvious optimal maintenance operation allowing the simultaneous optimization of all ecosystem services provided by ditches. All maintenance operations globally impact, in a positive way, waterlogging control or soil erosion prevention and, in negative way, biodiversity conservation. The effects of maintenance operations on groundwater recharge, flood regulation, and water purification are more contrasted.

\subsection{Designing maintenance toward an optimization of ecosystem services}

This review shows that ditch maintenance operations exert a strong influence on several important ditch characteristics and on most of the processes (Table 5). Accordingly, it can be expected that the maintenance operations are adequate for optimizing the contribution of ditches to several ecosystem services. We tried to state the global impact of each operation on each range of service, similar to what has been performed between the operations and the ditch processes in Table 5. It is possible to distinguish three types of services according to the impact of the maintenance operations. The first type of service corresponds to the waterlogging and erosion prevention services for which all of the maintenance operations have a positive impact because they improve water conveyance. A second type of service corresponds to biodiversity conservation, which is negatively impacted by the maintenance operations except for mowing because these operations strongly disturb 
ditch vegetation and habitats. The third type of service corresponds to all of the other services for which no overall impact of operations can easily been defined. This result occurs for two reasons. These services depend on several processes for which the impacts of a given operation vary from positive to negative. Moreover, the respective contributions of the processes to the setting of the service are either unknown or vary with local conditions, preventing the determination of the operation impacts of the services on the underlying processes.

Therefore, to move toward the application of ditch maintenance operations to improve ecosystem services, this review also indicates areas where progress must be made in terms of process knowledge or experimentation.

- Burning is the least studied operation. To better understand the impacts of burning on ditch processes and services, several specific mechanisms that are likely to occur after burning must be explored: (i) the contribution of ashes to the deterioration of water turbidity, (ii) the change in the hydraulic friction because burning enhances the vegetation growth and selects vegetation species, (iii) the net balance for biodiversity, (iv) the impact on soil infiltrability and, therefore, on the subsurface water collection and groundwater recharge, and (v) the change in the retention and degradation capacities of pesticides. For the fifth mechanism, burned plant residues were shown to be preferential sorption sites (Yang and Sheng 2003a, b), but it is not clear whether these new sorption sites can compensate in ditches for the removal of other sites (litter and living vegetation). In a case study, Xu et al. (2008) observed that pesticide sorption increased after burning and caused the consequent reduction in the degradation rate.

- Mowing is an interesting practice that has, if performed at an adequate season, no or little adverse effects on biodiversity because it permits rapid vegetation regrowth and favors seed dispersal. Moreover, mowing without the removal of mowed vegetation should produce a new litter that can positively change ditch bed properties. More indepth knowledge is required on mowing impacts, including (i) the effect of mowed residues on the pollutant retention and degradation capacities, infiltration processes, and hydraulic roughness of ditches and (ii) the effect of regular mowing on the diversity of plant species and, therefore, on the ditch properties.

- The impacts of a succession of maintenance operations need to be examined. The vast majority of the work that we reported concerned the study of the effects of single maintenance operations, whereas actual ditch maintenance consists of a temporal succession of operations, which are selected from the four basic operations. Thus, improving the maintenance strategies of ditches for agroecological engineering also requires an optimal succession of operations. It is necessary to define which specific ditch services are foremost expected at a given time and to select the correct operation for favoring these services. Process investigation entails examining whether antecedent maintenance operations influence the outcome of current maintenance operations and studying the possibility of the long-term effects of a combination of operations.

In sum, mowing appears as an interesting maintenance operation with limited adverse effects on biodiversity conservation or water purification when performed at an adequate season and positive effects on waterlogging control and soil erosion prevention. The effect of burning has been poorly investigated. Maintenance is a succession in time of various operations. Improving the maintenance strategies of ditches for agroecological engineering requires an optimal succession of operations.

\section{Conclusion}

This review shows that ditches provide many regulating ecosystem services, namely, waterlogging control, water erosion control, water purification, flood regulation, groundwater recharge, and biodiversity. Sustainable agroecological engineering of cultivated landscapes relies on the optimization of these ecosystem services. This review also details the range of landscape processes involved in these services, which act on catchment hydrology, erosion and sediment transfers, pesticide and nutrient sources and fate, and biodiversity. Several ditch characteristics that influence these processes were shown to be amendable by ditch maintenance operations (e.g., dredging, mowing, chemical weeding, and burning). Accordingly, the review demonstrates that ditch maintenance can be a powerful lever for improving the services provided by ditches.

The interactions between the various processes that are involved in the ditch services and the simultaneous impacts of ditch characteristics on many services however make these services strongly interdependent. Therefore, maximizing a given service may lead to unexpected positive or negative feedbacks on other services. These feedbacks not only can be local and immediate but can also be shifted in space (e.g., downstream and from the surface to the ground) or in time (e.g., a delayed effect).

Determining a relevant strategy of ditch maintenance for improving a range of ditch services remains therefore a very challenging task. Our review indicates several related research needs. First, a better understanding of the impacts of the maintenance practices on each service is needed, which, in turn, requires a better understanding of some still poorly studied processes (e.g., sorption and degradation of pollutants in ditches and shelter provision) and better determinations and mapping of key ditch characteristics (e.g., hydraulic 
properties, vegetation characteristics, and sorption properties). Secondly, when several services are to be considered, efficient strategies of overall maximization should be defined. They can take advantage of the rather different timescale and "critical schedule" of each service. They should aim at optimizing the spatial arrangement of the different maintenance practices on ditches according to catchment heterogeneity (soil, climate, topography) and ditch connectivity. They need an a priori ranking of the expected services. The ranking may be specified by the local context as, for example, the supply of freshwater for human consumption where the water purification service should be favored. This ranking requires a valuation of the services by the different stakeholders, e.g., from a participatory evaluation (Weaver and Cousins 2005). Eventually, for building the strategies, new knowledge should be acquired on the feedbacks between processes, which most often, as indicated by our review, were studied separately.

Given the large number of ditch characteristics and processes to consider, the numerous positive and negative feedbacks between services, and the different spatial and temporal scales that should be taken into account, in situ experiments of ditch maintenance strategies cannot address all management issues, especially when ditch management has to be defined over long term for a sustainable agroecological engineering of landscapes. Consequently, in our opinion, a scientific challenge in the future will also be the development of numerical explicit modeling approaches at the landscape scale for integrating and coupling the major processes involved in the provision of landscape services by ditches. This should positively complement the experiments for analyzing and defining best management practices of ditches.

Acknowledgments This work was achieved in the framework of a research and development project funded by the French Office for Water and Aquatic Bodies (ONEMA). The first author is grateful to the French National Institute for Agricultural Research (INRA) for providing her $\mathrm{PhD}$ grant. We would like to thank the editors of Agronomy for Sustainable Development and the reviewers for their advices.

\section{References}

Abbot CL, Leeds-Harrison PB (1998) Research priorities for agricultural drainage in developing countries http://r4d.dfid.gov.uk/Output/ 5268/Default.aspx. Accessed 8 Jul 2014

Abu-Taleb MF (1999) The use of infiltration field tests for groundwater artificial recharge. Environ Geol 37:64-71

Acreman MC, Fisher J, Stratford CJ, Mould DJ, Mountford JO (2007) Hydrological science and wetland restoration: some case studies from Europe. Hydrol Earth Syst Sci 11:158-169

Agreste (2010) Recensement agricole. http://agreste.agriculture.gouv.fr/ recensement-agricole-2010/. Accessed 29 Jan 2014

ANSES (2014) Agritox database. http://www.agritox.anses.fr/. Accessed 8 Jul 2014
Arnold GW (1983) The influence of ditch and hedgerow structure, length of hedgerows, and area of woodland and garden on bird numbers on farmland. J Appl Ecol 20:731-750. doi:10.2307/2403123

Batlle-Aguilar J, Cook PG (2012) Transient infiltration from ephemeral streams: a field experiment at the reach scale. Water Resour Res. doi: 10.1029/2012WR012009

Belaud G, Baume J-P (2002) Maintaining equity in surface irrigation network affected by silt deposition. J Irrig Drain Eng 128(5):316325

Bellavance M-E, Brisson J (2010) Spatial dynamics and morphological plasticity of common reed (Phragmites australis) and cattails (Typha sp.) in freshwater marshes and roadside ditches. Aquat Bot 93:129134. doi:10.1016/j.aquabot.2010.04.003

Bennett ER, Moore MT, Cooper CM, Smith S Jr, Shields FD Jr, Drouillard KG, Schulz R (2005) Vegetated agricultural drainage ditches for the mitigation of pyrethroid-associated runoff. Environ Toxicol Chem 24:2121-2127. doi:10.1897/04-357R.1

Bento-Gonçalves A, Vieira A, Úbeda X, Martin D (2012) Fire and soils: key concepts and recent advances. Geoderma 191:3-13. doi:10. 1016/j.geoderma.2012.01.004

Blann KL, Anderson JL, Sands GR, Vondracek B (2009) Effects of agricultural drainage on aquatic ecosystems: a review. Crit Rev Environ Sci Technol 39:909-1001. doi:10.1080/ 10643380801977966

Boutron O, Margoum C, Chovelon J-M, Guillemain C, Gouy V (2011) Effect of the submergence, the bed form geometry, and the speed of the surface water flow on the mitigation of pesticides in agricultural ditches. Water Resour Res. doi:10.1029/2011WR010378

Bracken LJ, Wainwright J, Ali GA, Tetzlaff D, Smith MW, Reaney SM, Roy AG (2013) Concepts of hydrological connectivity: research approaches, pathways and future agendas. EARTH-Sci Rev 119: 17-34. doi:10.1016/j.earscirev.2013.02.001

Bradbury RB, Kirby WB (2006) Farmland birds and resource protection in the UK: cross-cutting solutions for multi-functional farming? Biol Conserv 129:530-542. doi:10.1016/j.biocon.2005.11.020

Branger F (2003) Modélisation de l'influence d'un fossé en travers de la pente sur les écoulements - Conséquence sur le transfert de solutés. Dissertation, University Pierre et Marie Curie

Brown CD, Dubus IG, Fogg P, Spirlet M, Gustin C (2004) Exposure to sulfosulfuron in agricultural drainage ditches: field monitoring and scenario-based modelling. Pest Manag Sci 60:765-776. doi:10. $1002 /$ ps. 876

Buchanan BP, Falbo K, Schneider RL, Easton ZM, Walter MT (2012) Hydrological impact of roadside ditches in an agricultural watershed in Central New York: implications for non-point source pollutant transport. Hydrol Process. doi:10.1002/hyp.9305

Budd R, O'Geen A, Goh KS, Bondarenko S, Gan J (2009) Efficacy of constructed wetlands in pesticide removal from tailwaters in the Central Valley, California. Environ Sci Technol 43:2925-2930. doi:10.1021/es802958q

Burkart MR, Simpkins WW, Squillace PJ, Helmke M (1999) Tributary stream infiltration as a source of herbicides in an alluvial aquifer : farming systems impacts on water quality in Walnut Creek Watershed, Iowa. J Environ Qual 28:69-74

Carluer N, Gascuel C (2011) Un manuel en ligne pour comprendre la qualité des eaux de surface et ses déterminants -Chap. 3. http://agrotransfert-bretagne.univ-rennes1.fr/Territ_Eau/CONNAISSANCES/ referentiel_complet_partie2.pdf. Accessed 8 Jul 2014

Carluer N, Marsily G (2004) Assessment and modelling of the influence of man-made networks on the hydrology of a small watershed: implications for fast flow components, water quality and landscape management. J Hydrol 285:76-95

Childs EC, Youngs EG (2006) The nature of the drain channel as a factor in the design of a land-drainage system. J Soil Sci 9:316-331. doi: 10.1111/j.1365-2389.1958.tb01923.x 
Christen EW, Ayars JE, Hornbuckle JW (2001) Subsurface drainage design and management in irrigated areas of Australia. Irrig Sci 21:3543. doi:10.1007/s002710100048

Cooper CM, Moore MT, Bennett ER, Smith S Jr, Farris JL, Milam CD, Shields FD Jr (2004) Innovative uses of vegetated drainage ditches for reducing agricultural runoff. Water Sci Technol J Int Assoc Water Pollut Res 49:117-123

Crabit A, Colin F, Moussa R (2011) A soft hydrological monitoring approach for comparing runoff on a network of small poorly gauged catchments. Hydrol Process 25:2785-2800

Crerar S, Fry RG, Slater PM, van Langnehove G, Wheeler D (1988) An unexpected factor affecting recharge from ephemeral river flows in SWA/Namibia, in: (Ed.), I.S. (Ed.), Estimation of natural groundwater recharge. Reidel Publishing Company, pp. 11-28

Crum SJH, Kammen-Polman AMM, van Leistra M (1999) Sorption of nine pesticides to three aquatic macrophytes. Arch Environ Contam Toxicol 37:310-316. doi:10.1007/s002449900519

Crum SJH, Aalderink GH, Brock TCM (1997) Fate of the herbicide linuron in outdoor experimental ditches. Chemosphere 36:21752190. doi:10.1016/S0045-6535(97)10190-4

D'Itri FM, Belcher HW (1994) Subirrigation and controlled drainage. CRC Press

Dabney SM, Moore MT, Locke MA (2006) Integrated management of infield, edge-of-field, and after-field buffers. J Am Water Resour Assoc 42:15-24. doi:10.1111/j.1752-1688.2006.tb03819.x

Dages C, Voltz M, Bsaibes A, Prévot L, Huttel O, Louchart X, Garnier F, Negro (2009) Estimating the role of a ditch network in groundwater recharge in a Mediterranean catchment using a water balance approach. J Hydrol 375:498-512. doi:10.1016/j.jhydrol.2009.07.002

Das A (2007) Optimal design of channel having horizontal bottom and parabolic sides. J Irrig Drain Eng 133(2):192-197. doi:10.1061/ (ASCE)0733-9437(2007)133:2(192)

DeBano LF (2000) The role of fire and soil heating on water repellency in wildland environments: a review. J Hydrol 231-232:195-206. doi: 10.1016/S0022-1694(00)00194-3

Debieche TH, Adamiane CV, Carluer N (2006) Effet d'un fossé en travers de la pente sur l'écoulement hydrodynamique d'une nappe peu profonde. Applicatio n sur le site expérimental de la Jaillière (44, France). Presented at the International Groundwater Symposium: Groundwater Hydraulics in Complex Environments, Toulouse (France)

Delin GN, Landon MK (2002) Effects of topography on the transport of agricultural chemicals to groundwater in a sand-plain setting. Hydrogeol J 10:443-454

van Dijk WFA, van Ruijven J, Berendse F, de Snoo GR (2014) The effectiveness of ditch banks as dispersal corridor for plants in agricultural landscapes depends on species' dispersal traits. Biol Conserv 171:91-98. doi:10.1016/j.biocon.2014.01.006

Dousset S, Thévenot M, Schrack D, Gouy V, Carluer N (2010) Effect of grass cover on water and pesticide transport through undisturbed soil columns, comparison with field study (Morcille watershed, Beaujolais). Environ Pollut Barking Essex 158:2446-2453. doi:10. 1016/j.envpol.2010.03.028

Dunn SM, Mackay R (1996) Modelling the hydrological impacts of open ditch drainage. J Hydrol 179:37-66. doi:10.1016/0022-1694(95) 02871-4

Edwards AC, Withers PJA (2008) Transport and delivery of suspended solids, nitrogen and phosphorus from various sources to freshwaters in the UK. J Hydrol 350:144-153. doi:10.1016/j.jhydrol.2007.10. 053

Elsaesser D, Stang C, Bakanov N, Schulz R (2013) The Landau stream mesocosm facility: pesticide mitigation in vegetated flow-through streams. Bull Environ Contam Toxicol 90:640-645. doi:10.1007/ s00128-013-0968-9

Elsaesser D, Stang C, Schulz R (2011) Assessing the influence of vegetation on reduction of pesticide concentration in experimental surface flow constructed wetlands: application of the toxic units approach. Ecol Eng 37:955-962. doi:10.1016/j.ecoleng.2011.02. 003

Field JA, Reed RL, Sawyer TE, Griffith SM, Wigington PJ Jr (2003) Diuron occurrence and distribution in soil and surface and ground water associated with grass seed production. J Environ Qual 32: $171-179$

Fiener P, Auerswald K (2003) Effectiveness of grassed waterways in reducing runoff and sediment delivery from agricultural watersheds. J Environ Qual 32:927-936

Flint A, Flint L, Kwicklis E, Fabryka-Martin J, Bodvarsson G (2002) Estimating recharge at Yucca Mountain, Nevada, USA: comparison of methods. Hydrogeol J 10:180-204

Flora C, Kröger R (2014) Use of vegetated drainage ditches and lowgrade weirs for aquaculture effluent mitigation: II. Suspended sediment. Aquac Eng 60:68-72. doi:10.1016/j.aquaeng.2014.04.007

Förstner U, Heise S, Schwartz R, Westrich B, Ahlf W (2004) Historical contaminated sediments and soils at the river basin scale. J Soils Sediments 4:247-260. doi:10.1007/BF02991121

Galea G, Ramez P (1995) Maîtrise du ruisselement et de l'érosion en vignoble de coteaux. Cemagref Editions

Gallart F, Llorens P, Latron J (1994) Studying the role of old agricultural terraces on runoff generation in a small Mediterranean mountainous basin. J Hydrol 159:291-303. doi:10.1016/0022-1694(94)90262-3

Garcinuño RM, Fernandez Hernando P, Camara C (2006) Removal of carbaryl, linuron, and permethrin by Lupinus angustifolius under hydroponic conditions. J Agric Food Chem 54:5034-5039. doi:10. 1021/jf060850j

Garon-Boucher C (2003) Contribution à l'étude du devenir des produits phytosanitaires lors de l'écoulement dans les fosses: caractérisation physico-chimique et hydrodynamique. $\mathrm{PhD}$ dissertation, Joseph Fournier University

Gavin H (2003) Impact of ditch management on the water levels of a wet grassland in Southeast England. Agric Ecosyst Environ 99:51-60. doi:10.1016/S0167-8809(03)00201-9

Gebremariam SY, Beutel MW, Yonge DR, Flury M, Harsh JB (2012) Adsorption and desorption of chlorpyrifos to soils and sediments. Springer, New York, pp 123-175

Gill SL, Spurlock FC, Goh KS, Ganapathy C (2008) Vegetated ditches as a management practice in irrigated alfalfa. Environ Monit Assess 144:261-267. doi:10.1007/s10661-007-9988-4

Girard M-C, Walter C, Rémy J-C, Berthelin J, Morel J-L (2011) Sols et environnement, 2nd edn. Dunod, Paris

González-Pérez JA, González-Vila FJ, Almendros G, Knicker H (2004) The effect of fire on soil organic matter: a review. Environ Int 30: 855-870. doi:10.1016/j.envint.2004.02.003

Gumiere SJ, Le Bissonnais Y, Raclot D, Cheviron B (2011) Vegetated filter effects on sedimentological connectivity of agricultural catchments in erosion modelling: a review. Earth Surf Process Landf 36: 3-19. doi:10.1002/esp.2042

Herzon I, Helenius J (2008) Agricultural drainage ditches, their biological importance and functioning. Biol Conserv 141:1171-1183. doi:10. 1016/j.biocon.2008.03.005

Hillel D (1998) Environmental soil physics. Academic Press, Elsevier

Hösl R, Strauss P, Glade T (2012) Man-made linear flow paths at catchment scale: identification, factors and consequences for the efficiency of vegetated filter strips. Landsc Urban Plan 104:245-252. doi: 10.1016/j.landurbplan.2011.10.017

Huang C, Gascuel-Odoux C, Cros-Cayot S (2002) Hillslope topographic and hydrologic effects on overland flow and erosion. Catena 46: 177-188. doi:10.1016/S0341-8162(01)00165-5

Hughes DA, Sami K (1992) Transmission losses to alluvium and associated moisture dynamics in a semiarid ephemeral channel system in Southern Africa. Hydrol Process 6:45-53 
Jarvela J (2002) Flow resistance of flexible and stiff vegetation: a flume study with natural plants. J Hydrol 269:44-54. doi:10.1016/S00221694(02)00193-2

Jarvela J (2005) Effect of submerged flexible vegetation on flow structure and resistance. J Hydrol 307:233-241

Kao C, Vernet G, Filleul JML, Nédélec Y, Carluer N, Gouy V (2002) Élaboration d'une méthode de typologie des fossés d'assainissement agricole et de leur comportement potentiel vis-à-vis des produits phytosanitaires. Ingéniéries 29:49-65

Koivusalo H, Ahti E, Laurén A, Kokkonen T, Karvonen T, Nevalainen R, Finér L (2008) Impacts of ditch cleaning on hydrological processes in a drained peatland forest. Hydrol Earth Syst Sci 12:1211-1227

Kröger R, Dunne EJ, Novak J, King KW, McLellan E, Smith DR, Strock J, Boomer K, Tomer M, Noe GB (2013) Downstream approaches to phosphorus management in agricultural landscapes: regional applicability and use. Sci Total Environ 442:263-274. doi:10.1016/j. scitotenv.2012.10.038

Kröger R, Holland MM, Moore MT, Cooper CM (2007a) Hydrological variability and agricultural drainage ditch inorganic nitrogen reduction capacity. J Environ Qual 36:1646-1652. doi:10.2134/jeq2006. 0506

Kröger R, Holland MM, Moore MT, Cooper CM (2007b) Plant senescence: a mechanism for nutrient release in temperate agricultural wetlands. Environ Pollut 146:114-119. doi:10.1016/j.envpol.2006. 06.005

Kröger R, Holland MM, Moore MT, Cooper CM (2008) Agricultural drainage ditches mitigate phosphorus loads as a function of hydrological variability. J Environ Qual 37:107-113. doi:10.2134/ jeq2006.0505

Kröger R, Moore MT, Locke MA, Cullum RF, Steinriede RW Jr, Testa S III, Bryant CT, Cooper CM (2009) Evaluating the influence of wetland vegetation on chemical residence time in Mississippi Delta drainage ditches. Agric Water Manag 96:1175-1179. doi:10.1016/ j.agwat.2009.03.002

Lagacherie P, Diot O, Domange N, Gouy V, Floure C, Kao C, Moussa R, Robbez-Masson JM, Szleper V (2006) An indicator approach for describing the spatial variability of artificial stream networks with regard to herbicide pollution in cultivated watersheds. Ecol Indic 6: 265-279. doi:10.1016/j.ecolind.2005.02.003

Langheinrich U, Tischew S, Gersberg RM, Lüderitz V (2004) Ditches and canals in management of fens: opportunity or risk? A case study in the Drömling Natural Park, Germany. Wetl Ecol Manag 12:429445. doi:10.1007/s11273-004-0700-y

Lecce SA, Pease PP, Gares PA, Wang J (2006) Seasonal controls on sediment delivery in a small coastal plain watershed, North Carolina, USA. Geomorphology 73:246-260. doi:10.1016/j. geomorph.2005.05.017

Leng X, Musters CJM, de Snoo GR (2011) Effects of mowing date on the opportunities of seed dispersal of ditch bank plant species under different management regimes. J Nat Conserv 19:166-174. doi:10. 1016/j.jnc.2010.11.003

Levavasseur F (2012) Structure du paysage et fonctionnement hydrologique: application aux réseaux de fossés en zone viticole méditerranéenne. $\mathrm{PhD}$ dissertation, Montpellier SupAgro

Levavasseur F, Bailly JS, Lagacherie P, Colin F, Rabotin M (2012) Simulating the effects of spatial configurations of agricultural ditch drainage networks on surface runoff from agricultural catchments. Hydrol Process. doi:10.1002/hyp.8422

Levavasseur F, Biarnès A, Bailly JS, Lagacherie P (2014) Time-varying impacts of different management regimes on vegetation cover in agricultural ditches. Agric Water Manag 140:14-19. doi:10.1016/j. agwat.2014.03.012

Liu L, Hu H, Qi J (2012) Research on the influencing factors of hydraulic efficiency in ditch wetlands. Procedia Eng. 2012 International
Conference on Modern Hydraulic Engineering 28:759-762. doi: 10.1016/j.proeng.2012.01.804

Liu X, Zhang X, Zhang M (2008) Major factors influencing the efficacy of vegetated buffers on sediment trapping: a review and analysis. J Environ Qual 37:1667-1674. doi:10.2134/jeq2007.0437

Logan TJ (1993) Agricultural best management practices for water pollution control: current issues. Agric Ecosyst Environ 46:223-231. doi:10.1016/0167-8809(93)90026-L

Louchart X, Voltz M, Andrieux P, Moussa R (2001) Herbicide transport to surface waters at field and watershed scales in a Mediterranean vineyard area. J Environ Qual 30:982-991

Loumagne C, Tallec G (2013) L'observation long terme en environnement. http://www.quae.com/fr/r3191-1-observation-longterme-en-environnement.html. Accessed 8 Jul 2014

Mahabali S, Spanoghe P (2014) Mitigation of two insecticides by wetland plants: feasibility study for the treatment of agricultural runoff in Suriname (South America). Water Air Soil Pollut 225:1-12. doi: 10.1007/s11270-013-1771-2

Margoum C, Gouy V, Laillet B, Dramais G (2003) Rétention des produits phytosanitaires dans les fossés de connexion parcelle-cours d'eau. J Water Sci 16:389-405

Margoum C, Gouy V, Williams R, Smith J (2001) Le rôle des fossés agricoles dans la dissipation des produits phytosanitaires. Ingéniéries 56-65

Margoum C, Malessard C, Gouy V (2006) Investigation of various physicochemical and environmental parameter influence on pesticide sorption to ditch bed substratum by means of experimental design. Chemosphere 63:1835-1841. doi:10.1016/j.chemosphere.2005.10. 032

Marja R, Herzon I (2012) The importance of drainage ditches for farmland birds in agricultural landscapes in the Baltic countries: does field type matter? Ornis Fenn 89:170-181

Marofi S (1999) Rôle des échanges nappes-fossés dans le fonctionnement hydrologique d'un bassin versant en milieu méditerranéen cultivé. $\mathrm{PhD}$ dissertation, Montpellier SupAgro

Merritt WS, Letcher RA, Jakeman AJ (2003) A review of erosion and sediment transport models. Environ Model Softw 18(8):761-799

Millennium Ecosystem Assessment (2005) Ecosystems and human wellbeing. Island Press, Washington DC

Moore MT, Benett ER, Cooper CM, Smith SJ, Shields FDJ, Milam CD, Farris JL (2001) Transport and fate of atrazine and lambdacyhalothrin in an agricultural drainage ditch in the Mississippi Delta. USA Agric Ecosyst Environ 87:309-314

Moore MT, Denton DL, Cooper CM, Wrysinski J, Miller JL, Werner I, Horner G, Crane D, Holcomb DB, Huddleston GM (2011) Use of vegetated agricultural drainage ditches to decrease pesticide transport from tomato and alfalfa fields in California, USA. Environ Toxicol Chem 30:1044-1049. doi:10.1002/etc.474

Moore MT, Kröger R, Locke MA, Cullum RF, Steinriede RW Jr, Testa S III, Lizotte RE Jr, Bryant CT, Cooper CM (2010) Nutrient mitigation capacity in Mississippi Delta, USA drainage ditches. Environ Pollut 158:175-184. doi:10.1016/j.envpol.2009.07.024

Moussa R, Voltz M, Andrieux P (2002) Effects of the spatial organization of agricultural management on the hydrological behaviour of a farmed catchment during flood events. Hydrol Process 16:393412. doi:10.1002/hyp.333

Neal C, Heathwaite AL (2005) Nutrient mobility within river basins: a European perspective. J Hydrol 304:477-490. doi:10.1016/j. jhydrol.2004.07.045

Nédélec Y, Gay B (2008) Experimental study of a right-angled end junction between a pipe and an open channel. J Hydraul Eng 134:616625. doi:10.1061/(ASCE)0733-9429(2008)134:5(616)

Needelman BA, Kleinman PJA, Strock JS, Allen AL (2007) Improved management of agricultural drainage ditches for water quality protection: an overview. J Soil Water Conserv 62:171-178 
Nepf H (2012) Hydrodynamics of vegetated channels. J Hydraul Res 50: 262-279. doi:10.1080/00221686.2012.696559

Nguyen L, Sukias J (2002) Phosphorus fractions and retention in drainage ditch sediments receiving surface runoff and subsurface drainage from agricultural catchments in the North Island, New Zealand. Agric Ecosyst Environ 92:49-69. doi:10.1016/S0167-8809(01) 00284-5

Nourani V, Talatahari S, Monadjemi P, Shahradfar S (2009) Application of ant colony optimization to optimal design of open channels. 47 : 656-665. doi:10.3826/jhr.2009.3468

Pappas EA, Smith DR (2007) Effects of dredging an agricultural drainage ditch on water column herbicide concentration, as predicted by fluvarium techniques. J Soil Water Conserv 62:262-268

Passeport E, Benoit P, Bergheaud V, Coquet Y, Tournebize J (2011a) Selected pesticides adsorption and desorption in substrates from artificial wetland and forest buffer. Environ Toxicol Chem SETAC 30:1669-1676. doi:10.1002/etc.554

Passeport E, Benoit P, Bergheaud V, Coquet Y, Tournebize J (2011b) Epoxiconazole degradation from artificial wetland and forest buffer substrates under flooded conditions. Chem Eng J 173:760-765. doi: 10.1016/j.cej.2011.08.044

Poulard C, Chastan B, Royet P, Degoutte G, Grelot F, Erdlenbruch K, Nedelec Y (2008) Prévention des inondations par ralentissement dynamique: principe et recommandations. Aspects techniques et économiques des aménagements de ralentissement dynamique des crues. Ingénieries EAT special issue 14:5-24

Rhoads BL, Massey KD (2012) Flow structure and channel change in a sinuous grass-lined stream within an agricultural drainage ditch: implications for ditch stability and aquatic habitat. River Res Appl 28:39-52. doi:10.1002/rra.1430

Ritzema HP, Satyanarayana TV, Raman S, Boonstra J (2008) Subsurface drainage to combat waterlogging and salinity in irrigated lands in India: lessons learned in farmers' fields. Agric Water Manag 95: 179-189. doi:10.1016/j.agwat.2007.09.012

Rosenzweig C, Tubiello FN, Goldberg R, Mills E, Bloomfield J (2002) Increased crop damage in the US from excess precipitation under climate change. Glob Environ Chang 12:197-202. doi:10.1016/ S0959-3780(02)00008-0

Scholz M, Trepel M (2004) Water quality characteristics of vegetated groundwater-fed ditches in a riparian peatland. Sci Total Environ 332:109-122. doi:10.1016/j.scitotenv.2004.02.001

Simon TN, Travis J (2011) The contribution of man-made ditches to the regional stream biodiversity of the new river watershed in the Florida panhandle. Hydrobiologia 661:163-177. doi:10.1007/ s10750-010-0521-3

Skaggs RW (1992) Drainage and water management modeling technology. Am Soc Agric Eng

Skaggs RW, Chescheir GM, Phillips BD (2005) Methods to determine lateral effect of a drainage ditch on wetland hydrology. Am Soc Agric Eng 48:577-584

Skaggs RW, Schilfgaarde JV (1999) Agricultural drainage. Illustrated edition. American Society of Agronomy, Crop Science Society of America, Soil Science Society of America, Madison

Smith DR, Pappas EA (2007) Effect of ditch dredging on the fate of nutrients in deep drainage ditches of the Midwestern United States. J Soil Water Conserv 62:252-261

Sofia G, Prosdocimi M, Fontana GD, Tarolli P (2014) Modification of artificial drainage networks during the past half-century: evidence and effects in a reclamation area in the Veneto floodplain (Italy), Anthropocene. In press, doi: 10.1016/j.ancene.2014.06.005

Sorman AU, Abdulrazzak MJ, Morel-Seytoux HJ (1997) Groundwater recharge estimation from ephemeral streams. Case study: Wadi Tabalah, Saudi Arabia. Hydrol Process 11:1607-1619

Stehle S, Elsaesser D, Gregoire C, Imfeld G, Niehaus E, Passeport E, Payraudeau S, Schäfer RB, Tournebize J, Schulz R (2011)
Pesticide risk mitigation by vegetated treatment systems: a metaanalysis. J Environ Qual 40:1068-1080. doi:10.2134/jeq2010.0510

Tang X, Zhu B, Katou H (2012) A review of rapid transport of pesticides from sloping farmland to surface waters: processes and mitigation strategies. J Environ Sci 24:351-361. doi:10.1016/S1001-0742(11) 60753-5

Tucker GE, Bras RL (1998) Hillslope processes, drainage density, and landscape morphology. Water Resour Res 34:2751-2764. doi:10. 1029/98WR01474

Twisk W, Noordervliet MW, Keurs WJ (2003) The nature value of the ditch vegetation in peat areas in relation to farm management. Aquat Ecol 37:191-209. doi:10.1023/A:1023944028022

Ulén BM, Larsbo M, Kreuger JK, Svanbäck A (2013) Spatial variation in herbicide leaching from a marine clay soil via subsurface drains. Pest Manag Sci. doi:10.1002/ps.3574

Vallée R, Dousset S, Billet D, Benoit M (2014) Sorption of selected pesticides on soils, sediment and straw from a constructed agricultural drainage ditch or pond. Environ Sci Pollut Res. doi:10.1007/ s11356-013-1840-5

Van Geert A, Van Rossum F, Triest L (2010) Do linear landscape elements in farmland act as biological corridors for pollen dispersal? J Ecol 98:178-187. doi:10.1111/j.1365-2745.2009.01600.x

VanderKwaak JE (1999) Numerical simulation of flow and chemical transport in integrated surface? Subsurface hydrologic systems. Dissertation, University of Waterloo

Vaughan RE, Needelman BA, Kleinman PJA, Rabenhorst MC (2008) Morphology and characterization of ditch soils at an Atlantic Coastal Plain farm. Soil Sci Soc Am J 72:660. doi:10.2136/ sssaj2006.0102

Verdonschot RCM, Keizervlek HE, Verdonschot PFM (2011) Biodiversity value of agricultural drainage ditches: a comparative analysis of the aquatic invertebrate fauna of ditches and small lakes. Aquat Conserv Mar Freshw Ecosyst 21:715-727. doi:10.1002/aqc. 1220

Voltz M, Louchart X (2001) Les facteurs-clés de transfert des produits phytosanitaires vers les eaux de surface. Special issue " Phytosanitaires », Ingénieries, EAT

Wan MT, Kuo J, McPherson B, Pasternak J (2006) Agricultural pesticide residues in farm ditches of the Lower Fraser Valley, British Columbia, Canada. J Environ Sci Health Part B Pestic Food Contam Agric Wastes 41:647-669. doi:10.1080/ 03601230600701817

Weaver L, Cousins JB (2005) Unpacking the participatory process. J Multi Disciplinary Eval 1:19-40

Westrich B, Förstner U (2007) Sediment dynamics and pollutant mobility in rivers. Springer

Williams P, Whitfield M, Biggs J, Bray S, Fox G, Nicolet P, Sear D (2004) Comparative biodiversity of rivers, streams, ditches and ponds in an agricultural landscape in Southern England. Biol Conserv 115:329 341. doi:10.1016/S0006-3207(03)00153-8

Wu FC, Hsieh Wen S, Chou Y-J (1999) Variation of roughness coefficients for unsubmerged and submerged vegetation. J Hydraul Eng 125:934-942

Xu C, Liu W, Sheng GD (2008) Burned rice straw reduces the availability of clomazone to barnyardgrass. Sci Total Environ 392:284-289. doi: 10.1016/j.scitotenv.2007.11.033

Yang Y, Sheng G (2003a) Enhanced pesticide sorption by soils containing particulate matter from crop residue burns. Environ Sci Technol 37: 3635-3639. doi:10.1021/es034006a

Yang Y, Sheng G (2003b) Pesticide adsorptivity of aged particulate matter arising from crop residue burns. J Agric Food Chem 51:5047-5051. doi:10.1021/jf0345301

Zhang Z-Y, Kong L-L, Zhu L, Mwiya RM (2013) Effect of drainage ditch layout on nitrogen loss by runoff from an agricultural watershed. Pedosphere 23:256-264. doi:10.1016/S1002-0160(13)60014-4 